\title{
11. OLD OCEANIC CRUST: SYNTHESIS OF LOGGING, LABORATORY, AND SEISMIC DATA FROM LEG 102 1
}

\author{
Matthew H. Salisbury, ${ }^{2}$ James H. Scott, ${ }^{3}$ Christian Auroux,${ }^{4}$ Keir Becker, ${ }^{5}$ Wilhelm Bosum, ${ }^{6}$ Cristina Broglia, ${ }^{7}$ \\ Richard Carlson, ${ }^{8}$ Nikolas I. Christensen, ${ }^{9}$ Andrew Fisher, ${ }^{10}$ Joris Gieskes, ${ }^{11}$ Mary Anne Holmes, ${ }^{12}$ \\ Hartley Hoskins, ${ }^{13}$ Dan Moos, ${ }^{7}$ Ralph Stephen, ${ }^{14}$ and Roy Wilkens ${ }^{15}$
}

\begin{abstract}
On ODP Leg 102, the JOIDES Resolution returned to Hole 418A at the southern end of the Bermuda Rise and logged the hole with a comprehensive suite of tools to determine the geophysical properties of old oceanic crust from insitu measurements. An excellent set of density, porosity, natural gamma-ray, conductivity, resistivity, full wave and multichannel sonic $(P$ and $S$ ), magnetic susceptibility, three-axis magnetometer, and caliper logs was obtained over varying intervals from 0 to $488 \mathrm{~m}$ within the basement. In addition, the sediments were logged through the pipe using the porosity and spectral gamma-ray tools, water samples were taken and temperature measurements made at selected depths in basement, and the oblique seismic experiment was successfully run with a three-component borehole seismometer clamped $41,81,230,330$, and $430 \mathrm{~m}$ within the basement.

The results demonstrate as follows:

1. Layer $2 \mathrm{~A}$ is absent: $\mathrm{V}_{p}$ increases gradually from $4.5 \mathrm{~km} / \mathrm{s}$ at the sediment/basement contact to $6.9 \mathrm{~km} / \mathrm{s}$ at $1.5 \mathrm{~km}$ within the basement and averages $4.8 \mathrm{~km} / \mathrm{s}$ in the upper $0.5 \mathrm{~km}$.

2. The upper crust is anisotropic: $V_{p}$ varies with azimuth by $\pm 0.2 \mathrm{~km} / \mathrm{s}$ to a range of $0.6 \mathrm{~km}$, with $\mathrm{V}_{p}$ fast parallel to spreading in the top of the section and fast subperpendicular to spreading near the bottom of the hole. In addition, the upper crust displays vertical/horizontal anisotropy, with $\mathrm{V}_{p}$ fast by $0.2 \mathrm{~km} / \mathrm{s}$ in the horizontal propagation direction.

3. The upper $0.5 \mathrm{~km}$ of the crust is cracked at all scales of investigation because $\mathrm{V}_{p_{\text {lab }}}>\mathrm{V}_{p_{\text {log }}}>\mathrm{V}_{p_{\mathrm{OSE}} \text {. }}$.

4. The average formation porosity of the section drilled is low (15\%, of which $10 \%$ is grain boundary porosity and $5 \%$ is fracture porosity) but was originally higher by an amount less than or equal to the present volume of clay in the formation $(9 \%)$.

5. The original formation porosity near the top of the section (Unit 5 and Subunit $8 \mathrm{~A}$ ) approached $40 \%$; the original velocity of this interval would have been about $3.5 \mathrm{~km} / \mathrm{s}$, or that of Layer $2 \mathrm{~A}$.

6. The disappearance of Layer $2 \mathrm{~A}$ was caused by infilling by an ordered sequence of alteration products formed by rock-water interaction in a closed system.
\end{abstract}

\footnotetext{
${ }^{1}$ Salisbury, M. H., Scott, J. H., et al., 1988. Proc. ODP, Sci. Results, 102: College Station, TX (Ocean Drilling Program).

2 Centre for Marine Geology, Dalhousie University, Halifax, Nova Scotia B3H 3J5, Canada.

${ }^{3}$ U.S. Geological Survey, Denver Federal Center, Denver, Colorado 80225 (present address: James H. Scott and Assoc., 12372 W. Louisiana Avenue, Lakewood, CO 80228).

4 Ocean Drilling Program, Texas A\&M University, College Station, TX 77843.

${ }^{5}$ Geological Research Division, Scripps Institution of Oceanography, University of California, La Jolla, CA 92093 (present address: Rosenstiel School of Marine and Atmospheric Science, University of Miami, Miami, FL 33149).

${ }^{6}$ Federal Institute for Geosciences and Natural Resources, D-3000 Hannover 51, P.O. Box 5101 53, Federal Republic of Germany.

7 Borehole Research Group, Lamont-Doherty Geological Observatory, Columbia University, Palisades, NY 10984 (Moos, present address: Department of Geophysics, Stanford University, Stanford, CA 94305). 77843 .

${ }^{8}$ Department of Geophysics, Texas A\&M University, College Station, TX

${ }^{9}$ Department of Earth and Atmospheric Sciences, Purdue University, West Lafayette, IN 47907.

10 Rosenstiel School of Marine and Atmospheric Science, University of Miami, Miami, FL 33149.

11 Ocean Research Division, Scripps Institution of Oceanography, University of California, La Jolla, CA 92093.

12 Department of Geology, University of Nebraska, Lincoln, NE 88588.

13 Ocean Industries Program, Woods Hole Oceanographic Institution, Woods Hole, MA 02543.

14 Department of Geology and Geophysics, Woods Hole Oceanographic Institution, Woods Hole, MA 02543.

15 Earth Resources Laboratory, Massachusetts Institute of Technology, Cam bridge, MA 02139 (present address: Department of Geology and Geophysics, University of Hawaii, 2525 Correa Road, Honolulu, HI 96822).
}

\section{INTRODUCTION}

In the middle 1970s, Houtz and Ewing (1976) recognized from seismic studies of the oceanic crust that Layer 2 could be subdivided into three layers, $2 \mathrm{~A}, 2 \mathrm{~B}$, and $2 \mathrm{C}$, on the basis of velocity (Table 1) and that the shallowest of these layers (2A) thinned and eventually disappeared with age. Because the upper levels of Layer 2 were known from dredging and shallow basement drilling to consist largely of pillow basalts, it was suggested by several authors (e.g., Schreiber and Fox, 1976) that the disappearance of Layer $2 \mathrm{~A}$ was due to the infilling of fractures and interpillow voids by alteration products, which raised the velocity to that typical of Layer 2B.

To test this hypothesis, the Deep Sea Drilling Project (DSDP) and the Ocean Drilling Program (ODP) drilled a transect of basement holes along a flow line extending from the crest of the Mid-Atlantic Ridge, where three holes (Holes 395A, 396B, and 648B) were drilled in young crust, to the edge of the Nares Abyssal Plain, where a series of holes was drilled at Sites 417 and 418 in crust of Cretaceous age at the southern end of the Bermuda Rise (Table 2). Although none of these holes penetrated much more than $0.5 \mathrm{~km}$ into basement, the differences between young and old crust at the sites are striking. At the site with the youngest crust (Hole 648B), where the section consists of extremely fresh pillow basalts, the crust proved virtually undrillable because of fractures and rubble. In Holes 395A and 
Table 1. Layered crustal velocity model of Houtz and Ewing (1976).

\begin{tabular}{lcc}
\hline Layer & $\begin{array}{c}\mathrm{v}_{p} \\
(\mathrm{~km} / \mathrm{s})\end{array}$ & $\begin{array}{c}\text { Thickness } \\
(\mathrm{km})\end{array}$ \\
\hline $2 \mathrm{~A}$ & $3.33 \pm 0.10$ & $0.74 \pm 0.23$ \\
$2 \mathrm{~B}$ & $5.23 \pm 0.44$ & $0.72 \pm 0.26$ \\
$2 \mathrm{C}$ & $6.19 \pm 0.16$ & $\mathrm{a}_{1.83} \pm 0.75$ \\
3 & $6.92 \pm 0.17$ & $\mathrm{~b}-$ \\
\hline a Cumulative thickness of Layers 2B \\
and 2C. \\
Thickness could not be determined \\
from sonobuoy studies.
\end{tabular}

and 396B (7 and 10 m.y. old, respectively), although incipient alteration had clearly set in and significant penetration was readily achievable, the pillow basalts remained, in general, quite fresh, recovery was poor, and logging indicated, at least in Hole $396 \mathrm{~B}$, that the section drilled belonged to Layer 2A (average $\mathrm{V}_{p}$ $=3.5 \mathrm{~km} / \mathrm{s}$; Kirkpatrick, 1979).

When drilling was first undertaken in old crust on Legs 5153 at Sites 417 and 418 (Fig. 1), it was immediately clear that the situation was very different. Whereas the basement sections drilled consisted primarily of pillow basalts as before, the basalts were strongly to profoundly altered in the upper few hundred meters of the basement: glass was completely replaced by palagonite, mafic phenocrysts and groundmass materials were extensively altered to clay, average $\mathrm{K}^{+}$values were high, and densities were depressed (Pritchard, 1980; Humphris et al., 1980; Pertsev and Rusinov, 1980; Juteau et al., 1980; Donnelly et al., 1980). In addition, recovery was unusually high (Table 2) and, for the first time, included significant amounts of vein material, interpillow void fillings, and annealed breccia (Pl. 1). Furthermore, the compressional-wave velocity obtained from sonic logging in the upper $100 \mathrm{~m}$ of Hole 417D $\left(\mathrm{V}_{p}=4.8 \mathrm{~km} / \mathrm{s}\right)$ and the oblique seismic experiment in the upper $250 \mathrm{~m}\left(\mathrm{~V}_{p}\right.$ increases from $4.8 \mathrm{~km} / \mathrm{s}$ at the top of the basement to $6.4 \mathrm{~km} / \mathrm{s}$ at a depth of $1.3 \mathrm{~km}$ within the basement) indicated that Layer $2 \mathrm{~A}$ was indeed absent (Stephen et al., 1980; Salisbury et al., 1980a, $1980 \mathrm{~b})$. It was thus concluded that the increased recovery and the disappearance of Layer $2 \mathrm{~A}$ were due to crustal "annealing" by alteration.

Although the results at Sites 417 and 418 are impressive, operational difficulties toward the end of Leg 53 prevented logging and further drilling in Hole 418A, the deepest and most promising of the holes drilled during Legs 51-53. When Hole 418A was finally terminated at a depth of $544 \mathrm{~m}$ within the basement, it had penetrated a complex section consisting of relatively fresh massive basalts from 0-63 $\mathrm{m}$ in the basement (Units 1-4; Table 3), altered pillow basalts from $63 \mathrm{~m}$ to the base of a thick breccia unit at a depth of $186 \mathrm{~m}$ (Unit 5 and Subunit 6A), and a thick unit of relatively fresh pillow basalts underlain by increasingly fresh, increasingly massive pillow basalts and massive basalts (some laced with dikes) toward the bottom of the hole (Subunits/Units $6 \mathrm{~B}$ to 16). Features of particular interest include a major polarity reversal coincident with breccia Subunit 6A (e.g., Levi 1980), increasingly steep magnetic inclinations with depth toward the base of the hole, and the recovery of core with residual stress from the lower levels of the hole.

Because of its depth and high core recovery, Hole 418A was regarded as an exceptional site at which to calibrate logging equipment and to determine the geophysical properties of old crust from logging and borehole experiments. Thus, Leg 102 returned to Hole 418A after an 8-yr hiatus, cleared the hole of obstructions, and conducted the most sophisticated series of downhole experiments ever attempted in an oceanic borehole, including a two-ship seismic experiment involving the R/V Fred $H$. Moore and a seismometer lowered into the hole from the JOIDES Resolution and multiple lowerings of conventional and experimental logging tools provided by Schlumberger and scientists from the United States and West Germany (Fig. 2 and Table 4).

\section{GEOLOGIC SETTING}

Hole 418A was drilled in 108-m.y.-old Cretaceous crust near the Vema Gap at the southern end of the Bermuda Rise. As can be seen in Figure 3, the site is located near the eastern edge of the $M 0$ anomaly, between two fracture zones that define the direction of spreading as $\mathrm{N} 68^{\circ} \mathrm{W}$. Although the region had been surveyed prior to drilling (Rabinowitz et al., 1980), a detailed survey had never been made in the immediate area of the drill holes. To rectify this situation, a series of seismic-reflection pro-

Table 2. Basement holes on DSDP/ODP Atlantic age transect.

\begin{tabular}{|c|c|c|c|c|c|c|c|c|c|}
\hline \multirow[b]{2}{*}{ Hole } & \multirow[b]{2}{*}{ Leg } & \multirow[b]{2}{*}{ Location } & \multirow{2}{*}{$\begin{array}{l}\text { Basement } \\
\text { penetration } \\
\text { (m) }\end{array}$} & \multirow[b]{2}{*}{$\begin{array}{c}\text { Recovery } \\
(\%)\end{array}$} & \multicolumn{3}{|c|}{ Recovered lithology $(\%)$} & \multirow[b]{2}{*}{$\begin{array}{c}\text { Age } \\
\text { (m.y.) }\end{array}$} & \multirow[b]{2}{*}{$\begin{array}{l}\text { Downhole } \\
\text { experiments }\end{array}$} \\
\hline & & & & & $\begin{array}{l}\text { Pillow } \\
\text { basalt }\end{array}$ & $\begin{array}{c}\text { Massive } \\
\text { basalt }\end{array}$ & Breccia & & \\
\hline$a, b 648 B$ & $106 / 109$ & $22^{\circ} 55.3^{\prime} \mathrm{N} ; 44^{\circ} 56.8^{\prime} \mathrm{W}$ & 51 & 12 & 60 & 40 & 0 & 0 & \\
\hline$c_{395 A}$ & 45 & $22^{\circ} 45.35^{\prime} \mathrm{N} ; 46^{\circ} 04.90^{\prime} \mathrm{W}$ & 580 & 18 & 78 & 15 & 7 & 7 & b,d Logging \\
\hline $\mathrm{e}_{396 \mathrm{~B}}$ & 46 & $22^{\circ} 59.14^{\prime} \mathrm{N} ; 43^{\circ} 30.90^{\prime} \mathrm{W}$ & 256 & 23 & $\mathrm{f}_{78}$ & $\mathrm{f}_{5}$ & $\mathrm{f}_{17}$ & 10 & ${ }^{3}$ Logging \\
\hline $\mathrm{h}_{417 \mathrm{~A}}$ & $51-53$ & $25^{\circ} 06.63^{\prime} \mathrm{N} ; 68^{\circ} 02.48^{\prime} \mathrm{W}$ & 209 & 61 & 75 & 9 & 16 & 108 & \\
\hline $\mathrm{h}_{417 \mathrm{D}}$ & $51-53$ & $25^{\circ} 06.69^{\prime} \mathrm{N} ; 68^{\circ} 02.82^{\prime} \mathrm{W}$ & 366 & 72 & 71 & 24 & 5 & 108 & $\begin{array}{l}{ }^{\mathrm{i}} \text { Logging, }{ }^{\mathrm{j}} \text { oblique } \\
\text { seismic experiment }\end{array}$ \\
\hline$k_{418 A}$ & $51-53$ & $25^{\circ} 02.10^{\prime} \mathrm{N} ; 68^{\circ} 02.82^{\prime} \mathrm{W}$ & 544 & 72 & 69 & 27 & 4 & 108 & $\begin{array}{l}\text { 'Logging, oblique } \\
\text { seismic experiment }\end{array}$ \\
\hline $\mathrm{k}_{418 \mathrm{~B}}$ & $51-53$ & $25^{\circ} 02.08^{\prime} \mathrm{N} ; 68^{\circ} 03.45^{\prime} \mathrm{W}$ & 10 & 74 & 100 & 0 & 0 & 108 & \\
\hline
\end{tabular}

a A. Adamson, pers. comm., 1987.

b Leg 109 Shipboard Scientific Party, 1986.

c Shipboard Scientific Party, 1979a.

d Hyndman, Salisbury, et al., 1984.

e Shipboard Scientific Party, 1979b.

${ }^{f}$ Based on Units 1-5.

${ }^{8}$ Kirkpatrick, 1979.

h Shipboard Scientific Parties, 1980a.

i Salisbury et al., 1980a.

${ }^{j}$ Stephen et al., 1980.

${ }^{k}$ Shipboard Scientific Parties, 1980b.

1 Shipboard Scientific Party, 1986. 


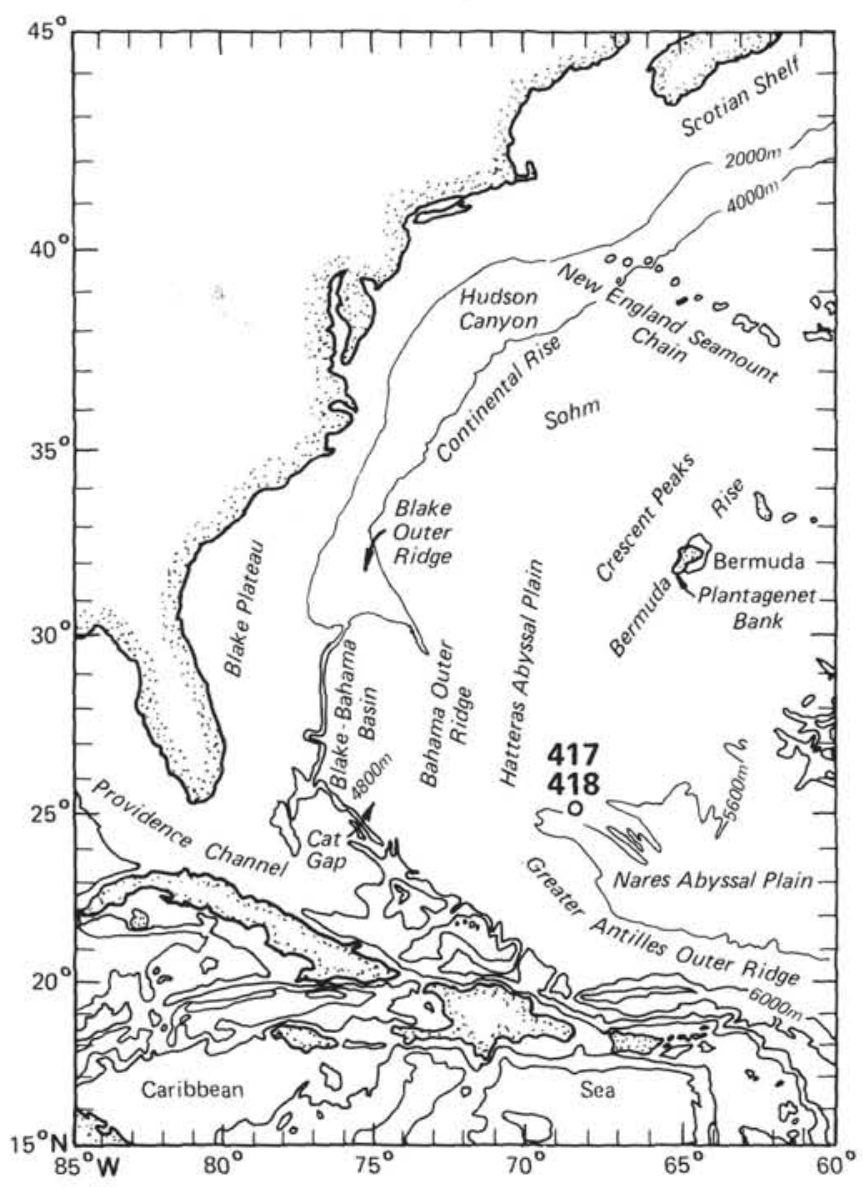

Figure 1. Location of Sites 417 and 418.

files was run from the Moore along grid lines covering a squareshaped area, with sides of about $16 \mathrm{~km}$, centered on Hole 418A (Fig. 4) while waiting for the geophysical logging of Hole 418A to be completed aboard the JOIDES Resolution.

The profiles indicate that the hole is located on the eastern edge of an irregularly shaped, bedrock valley (Fig. 5) trending approximately $\mathrm{N} 20^{\circ} \mathrm{E}$ and filled with over $300 \mathrm{~m}$ of sediments. Relief on the basalt bedrock surface is strong, with dips as great as $14 \%$. The seafloor terrain generally follows the pattern of the basalt surface, but with muted relief and maximum dips of only $5 \%$ or so. A reflector within the sediments is believed to represent the top of the middle Eocene (Unit III).

\section{SEISMIC VELOCITY STRUCTURE OF THE CRUST}

During the original drilling operations in 1977, an oblique seismic experiment (OSE) was conducted in Hole 417D to study the seismic velocity structure around the drill site and to determine whether seismic anisotropy is present in the upper levels of the crust. Because of drilling and instrument problems (the lower part of the hole was blocked by pipe; only the vertical component of the borehole seismometer could be made to operate), the experiment was not as comprehensive as originally planned. Nonetheless, the excellent data obtained showed that anisotropy was present in the upper levels of the hole and that compressional- and shear-wave velocities increased from $\mathrm{V}_{p}=$ 4.6 and $V_{s}=2.6 \mathrm{~km} / \mathrm{s}$ at the top of the basement to values typical of Layer 3 (6.8 and $3.6 \mathrm{~km} / \mathrm{s}$, respectively) at a depth of between 1.5 and $1.6 \mathrm{~km}$ (Stephen et al., 1980; Stephen and Harding, 1983).

On Leg 102, a much more extensive OSE was successfully conducted with the Moore providing a series of explosive and air gun shots in a pattern of radial and concentric lines centered on Hole 418A (Swift and Stephen, this volume). A three-component geophone was clamped at five different depths ranging from 41 to $430 \mathrm{~m}$ within the basement. The shooting patterns, which were different for different geophone depths, are shown diagrammatically in Figure 6, and typical ray paths are shown in Figure 7.

The data from the OSE were reduced in three ways. In the simplest, vertical seismic profile (VSP) treatment, interval velocities were calculated from vertical incidence traveltimes with the seismometer clamped $81,230,330$, and $430 \mathrm{~m}$ within the basement. This gives accurate compressional-wave values for a vertical propagation path in the immediate vicinity of the borehole (Table 5A).

In a second approach, the inflection point method (Stephen and Harding, 1983) was used to determine compressional-wave velocities at the seismometer clamp points from the radial shooting lines. The velocities calculated by this means (Table 5B) represent $P$-wave velocities for subhorizontal propagation paths sampling a large volume of rock in the vicinity of the hole. Values were calculated both before and after reduction to basement, but the former values are preferred because they are consistent with observed traveltimes.

In the third approach, compressional-wave velocities were determined using $\tau-\zeta$ inversion (Dorman and Jacobson, 1981). This technique allows compressional-wave velocities to be determined to depths considerably greater than that of the borehole (Table 5C), again for relatively long subhorizontal propagation paths. Shear-wave velocities were then calculated from the compressional-wave data assuming

$$
\mathrm{V}_{s}=0.55 \mathrm{~V}_{p} .
$$

Although not rigorously determined, the shear-wave velocities derived by this means would appear to be approximately correct, because synthetic seismograms generated from these values using the reflectivity method (Fuchs and Müller, 1971) are consistent with observed OSE data (e.g., Fig. 8).

Finally, traveltimes from the circular shooting lines to the borehole receiver were analyzed to determine anisotropy vs. range and depth. Pronounced $P$-wave anisotropy $( \pm 0.22 \mathrm{~km} / \mathrm{s})$ was observed at Site 418 (Fig. 9) in the upper $0.5 \mathrm{~km}$ of the basement and within $0.6 \mathrm{~km}$ of the hole but was absent at greater depths and ranges. Curiously, the fast direction for $V_{p}$ is parallel to spreading in the upper levels of the hole but becomes subperpendicular at depth.

As can be seen in Figure 10, subtle differences in $P$-wave velocity result from different reduction techniques. The $\tau-\zeta$ and inflection (before reduction to basement) methods are in excellent agreement, giving average velocities $\left(\mathrm{V}_{p}\right)$ in the upper 0.5 $\mathrm{km}$ of $4.8 \mathrm{~km} / \mathrm{s}$, but both give higher average velocities than the VSP method $(4.63 \mathrm{~km} / \mathrm{s})$. If this difference is real, then the upper crust is anisotropic to at least $430 \mathrm{~m}$ with $\mathrm{V}_{p}$ fast in the horizontal direction, as suggested by Newmark et al. (1985) for Hole 504B on the basis of borehole televiewer data. Regardless of anisotropy and however reduced, the $P$-wave velocities obtained by the OSE equal or exceed $4.5 \mathrm{~km} / \mathrm{s}$ at the top of the basement and increase with depth to values typical of Layer 3 at a depth of about $1.5 \mathrm{~km}$. This is in excellent agreement with the OSE results at Site 417 and confirms that Layer $2 \mathrm{~A}$ is absent.

\section{WELL LOGGING}

Following the initial pipe lowerings for temperature measurements and water sampling, pipe was run $488 \mathrm{~m}$ into the basalt to clear the hole of bridges and then raised to $42 \mathrm{~m}$ above the basalt/sediment contact, after which a full suite of conventional and experimental well logs was run in the borehole. The conventional logs were run by Schlumberger and included sonic $(P$ - 
Table 3. Basement lithologic units, Hole 418A, from results of Legs 52 and 53 (Shipboard Scientific Parties, 1980b).

\begin{tabular}{|c|c|c|c|c|c|c|}
\hline \multirow[b]{2}{*}{$\begin{array}{l}\text { Unit/ } \\
\text { subunit }\end{array}$} & \multicolumn{2}{|c|}{ Depth $^{\mathrm{a}}$} & \multirow[b]{2}{*}{$\begin{array}{l}\text { Thickness } \\
\text { (m) }\end{array}$} & \multirow[b]{2}{*}{$\begin{array}{l}\text { Type of } \\
\text { cooling unit }\end{array}$} & \multirow[b]{2}{*}{$\begin{array}{l}\text { Phenocryst } \\
\text { assemblage }^{b}\end{array}$} & \multirow[b]{2}{*}{$\begin{array}{c}\text { Interval } \\
\text { (core, section, } \mathrm{cm} \text { ) }\end{array}$} \\
\hline & $\begin{array}{c}\text { below } \\
\text { seafloor }(m)\end{array}$ & $\begin{array}{c}\text { in } \\
\text { basement }(\mathrm{m})\end{array}$ & & & & \\
\hline 1 & $324.0-329.6$ & $0-5.6$ & 5.6 & Pillow basalt & Plag-(Oliv) & $15-1,20$ to $16-1,10$ \\
\hline $2 \mathrm{~A}$ & $329.6-331.7$ & $5.6-7.7$ & 2.1 & Massive basalt & Plag-(Oliv) & $16-1,10$ to $16-2,105$ \\
\hline 2B & $331.7-339.0$ & $7.7-15.0$ & 7.3 & Massive basalt & Plag-(Oliv) & $16-2,105$ to $17-4,150$ \\
\hline $2 \mathrm{C}$ & $339.0-363.1$ & $15.0-39.1$ & 24.1 & Massive basalt & Plag-(Oliv) & $18-1,0$ to $20-5,81$ \\
\hline 2D & $363.1-376.6$ & $39.1-52.6$ & 13.5 & Massive basalt & Plag-(Oliv)-[Cpx] & $20-5,81$ to $24-1,57$ \\
\hline 3 & $376.6-383.3$ & $52.6-59.3$ & 6.7 & Pillow basalt & Plag-(Oliv)-[Cpx] & $24-1,57$ to $25-2,60$ \\
\hline 4 & $383.3-387.1$ & $59.3-63.1$ & 3.8 & Massive basalt & Plag-(Oliv)-[Cpx] & $25-2,60$ to $26-2,110$ \\
\hline 5 & $387.1-498.5$ & $63.1-174.5$ & 111.4 & $\begin{array}{l}\text { Pillow basalt and } \\
\text { breccia }\end{array}$ & Plag-(Oliv)-[Cpx] & $26-2,110$ to $40-3,47$ \\
\hline $6 \mathrm{~A}$ & $498.5-510.5$ & $174.5-186.5$ & 12.0 & Breccia & Plag-Oliv-(Sp)-[Cpx] & $41-1,0$ to $42-2,150$ \\
\hline $6 \mathrm{~B}$ & $510.5-611.0$ & $186.5-287.0$ & 100.5 & Pillow basalt & Plag-Oliv-(Sp)-[Cpx] & $42-3,0$ to $53-3,150$ \\
\hline 7 & $611.0-629.2$ & $287.0-305.2$ & 18.2 & Pillow basalt & Plag-Oliv-Cpx & $54-1,0$ to $55-7,70$ \\
\hline $8 \mathrm{~A}$ & $629.2-632.9$ & $305.2-308.9$ & 3.7 & Pillow basalt & Plag-Oliv-Cpx & $55-7,70$ to $56-3,45$ \\
\hline $8 \mathrm{~B}$ & $632.9-636.3$ & $308.9-312.3$ & 3.4 & Massive(?) basalt & Plag-Oliv-Cpx & $56-3,45$ to $56-5,125$ \\
\hline $8 \mathrm{C}$ & $636.3-671.8$ & $312.3-347.8$ & 35.5 & Pillow basalt & Plag-Oliv-Cpx & $56-5,125$ to $60-4,33$ \\
\hline 9 & $671.8-676.5$ & $347.8-352.5$ & 4.7 & $\begin{array}{l}\text { Massive, vesicular } \\
\text { basalt }\end{array}$ & Plag & $60-4,33$ to $60-6,66$ \\
\hline 10 & $676.5-686.0$ & $352.5-362.0$ & 9.5 & Massive basalt & Plag & $61-1,0$ to 61 bit, 95 \\
\hline 11 & $686.0-695.5$ & $362.0-371.5$ & 9.5 & Pillow basalt & Plag-Cpx-Oliv & $62-1,0$ to $63-5,119$ \\
\hline 12 & $695.5-698.2$ & $371.5-374.2$ & 2.7 & Massive(?) basalt & Plag-Cpx-Oliv & $64-1,0$ to $64-2,122$ \\
\hline 13 & $698.2-786.5$ & $374.2-462.5$ & 88.3 & $\begin{array}{l}\text { Pillow basalt and } \\
\text { breccia }\end{array}$ & Plag-Cpx-Oliv & $64-2,122$ to $75-4,150$ \\
\hline $14 \mathrm{~A}$ & $786.5-793.6$ & $462.5-469.6$ & 7.1 & Massive basalt & Plag-Cpx-Oliv & $75-5,0$ to $77-1,50$ \\
\hline $14 \mathrm{~B}$ & $793.6-821.5$ & $469.6-497.5$ & 27.9 & Massive basalt & Plag-Cpx-Oliv & $77-1,50$ to $79-7,124$ \\
\hline $14 \mathrm{C}$ & $821.5-859.8$ & $497.5-535.8$ & 38.3 & Massive basalt & Plag-Cpx-Oliv & $80-1,0$ to $86-1,25$ \\
\hline $15 \mathrm{~A}$ & c- & - & - & Basalt dikes & Plag-Oliv-Cpx & $\begin{array}{l}79-1,75 \text { to } 79-1,110 \\
79-2,78 \text { to } 79-1,105 \\
79-3,105 \text { to } 79-4,95\end{array}$ \\
\hline $15 \mathrm{~B}$ & - & - & - & Basalt dikes & Plag-Oliv & $\begin{array}{l}80-2,117 \text { to } 80-3,127 \\
80-4,2 \text { to } 80-4,42 \\
80-4,107 \text { to } 80-5,110\end{array}$ \\
\hline 16 & $859.8-868.0$ & $535.8-544.0$ & 8.2 & $\begin{array}{l}\text { Pillow basalt and } \\
\text { breccia }\end{array}$ & Plag-Oliv-Cpx-Sp & $86-1,25$ to $86-6,55$ \\
\hline
\end{tabular}

\footnotetext{
a Depths corrected for spacers.

${ }^{b}$ Plag = plagioclase; Oliv = olivine; $\mathrm{Cpx}=$ clinopyroxene; $\mathrm{Sp}=$ spinel.

c Undetermined.
}

and full wave), induction and spherically focused resistivity, natural and spectral gamma-ray, gamma density, neutron porosity, and caliper logs. The experimental logs were run by the Bundesanstalt für Geowissenschaften und Rohstoffe (BGR) of the Federal Republic of Germany, the United States Geological Survey, and Lamont-Doherty Geological Observatory and included magnetic field, magnetic susceptibility, and multichannel sonic logs. Most of the logs were run from near the top of the basement to a depth of $460 \mathrm{~m}$ or more within the basement, passing through most of the lithologic sequence drilled on Legs 51-53 (Table 3). The Schlumberger spectral gamma-ray and neutron porosity logs were run in the sediments above the basalts, but these measurements were somewhat degraded because they had to be made through the drill pipe to avoid problems of caving and bridging. The uppermost section of the susceptibility log extends $30 \mathrm{~m}$ into the sediments. Figure 2 shows the depth intervals covered by all of the logs, and Table 4 gives information on how the logs were run, along with an indication of the relative quality of the data. Figure 11 shows a selection of the most important logs together with lithology. Table 6 presents a summary of the properties of the basement section for lithologic Subunits/Units 1$13 \mathrm{C}$ based on these logs, and Table 7 gives the average corrected formation properties for the three major depth intervals logged in Hole 418A (Broglia and Moos, this volume).

As expected, an examination of Table 7 shows a positive correlation between total formation porosity and natural gamma radiation and a negative correlation between porosity and density, velocity, resistivity, and susceptibility. Many other features, however, are unusual; the average formation velocity at Site 418 is high $\left(\mathrm{V}_{p}=5.07 \mathrm{~km} / \mathrm{s}\right)$, as is the formation density $(2.6$ $\mathrm{g} / \mathrm{cm}^{3}$ ), whereas the porosity is low $(15 \%)$. Furthermore, the natural gamma radioactivity is high, especially in the upper levels of the section (23 GAPI units in Unit 5-Subunit 6A). Using the relationship between natural gamma radiation and clay content in cores, Broglia and Moos (this volume) computed a clay $\log$ that shows clay constitutes nearly $20 \%$ of the rock in Unit 5 and Subunit $6 \mathrm{~A}$ but is an order of magnitude less at greater depths in the hole. From the clay and velocity logs, they were able to estimate primary and secondary (fracture) porosity vs. depth and to demonstrate that the upper $0.5 \mathrm{~km}$ of the crust at Site 418 is about $10 \%$ primary porosity and $5 \%$ cracks by volume, in excellent agreement with earlier estimates from logging at Site 417 (Salisbury et al., 1980a).

The 12-channel full waveform log obtained in the lower section of the hole between 469 and $788 \mathrm{~m}$ provided high-quality $P$-wave data that generally confirmed the validity of the Schlumberger sonic log $(P$-wave) and also provided excellent $S$-wave data. However, the average $P$ - and $S$-wave velocities obtained ( 5.5 and $2.9 \mathrm{~km} / \mathrm{s}$, respectively) are generally higher than velocities obtained for the same interval and propagation direction with the borehole seismometer (Fig. 10), suggesting that the latter senses cracks that lie beyond the borehole wall and thus, are not seen by the sonic-logging tools.

As expected, the logs obtained with the three-axis magnetometer and the magnetic susceptibility tool (Bosum and Scott, this volume) were consistent with data obtained from the core on Legs 51-53 (e.g., Levi et al., 1980). The magnetometer, which is gyroscope-stabilized, picked up the magnetic field reversal seen in core samples above breccia Subunit $6 \mathrm{~A}$ at $180 \mathrm{~m}$ within the basement and measured a Cretaceous pole position consis- 
tent with the age of the site (the first such determination ever made in oceanographic research).

In addition to determining formation properties from logs as a function of depth for crustal studies, it was recognized that Hole $418 \mathrm{~A}$, with its high core recovery, provided an unusual opportunity to study logging tool responses in a variety of mafic rock types. Figure 12 shows the average values and statistical ranges ( \pm 1 standard deviation) of the properties obtained by the density, neutron porosity, velocity ( $\mathrm{V}_{p}$ from long-spaced sonic), resistivity (spherically focused $l o g$ ), radioactivity (natural gammaray), and magnetic susceptibility tools for breccias (Subunit 6A), altered pillow basalts (Unit 5), "fresh" pillow basalts (Subunits/ Units $6 \mathrm{~B}, 7,8 \mathrm{~B}, 8 \mathrm{C}, 11,13 \mathrm{~A}$, and $13 \mathrm{C}$ ), massive vesicular basalt (Unit 9), and massive basalt (Subunits/Units 8B, 10, 12, and 13B). The upper massive basalts (Subunits 2A-2D and Unit 4) were excluded from the averages because density logs were not available in these intervals.

Figure 12 shows that the average values and ranges of density, velocity, resistivity, and susceptibility tend to increase and that the averages and ranges of porosity and radioactivity tend to decrease with decreasing fracturing and alteration. These relationships, though based on a limited data set, suggest that it may be possible to differentiate between different basaltic rock types (massive, altered pillows, breccia, etc.) by running statistical analyses on well-log and core data from a well-characterized hole and then using the results to predict rock type as a function of a suite of well-log values and the statistical relationships established. In addition, it may be possible to determine, at least semiquantitatively, the degree of fracturing and alteration associated with the various rock types. Now that the DSDP/ODP data base of well-log and lithologic information on oceanic basalts is fairly large and of rather high quality, it might be appropriate to investigate these possibilities further by testing the validity and accuracy of identifying rock type and rock character by computer. Such an approach would be particularly useful for establishing lithology-depth relationships where core recovery is poor.

\section{COMPARISON OF LABORATORY, LOG, AND SEISMIC DATA}

During the course of Legs 51-53 and the follow-up laboratory studies on samples from Holes 417D and 418A, a vast amount of information was gathered on the physical properties of samples from old oceanic crust (Shipboard Scientific Parties, 1980a, 1980b; Hamano, 1980; Christensen et al., 1980; Johnson, 1980). This and the logging data are summarized in Table 7, and individual values of compressional-wave velocity, wet-bulk density, and porosity measured at atmospheric pressure on samples from Hole 418A are superimposed on the corrected logs in Figure 13 (Broglia and Moos, this volume). Though the agreement between laboratory and logging data is much better than is commonly observed in oceanic crust (see, for example, Kirkpatrick, 1979) and is excellent in selected units (for example, massive basalt Units 2 and 10), the logging velocities and densities are generally lower and the porosities higher than laboratory values. This indicates, as does the seismic anisotropy detected by the OSE, that cracks still exist.

Because of the number and quality of velocity studies conducted in the borehole and on samples from the core, Hole $418 \mathrm{~A}$ presents an unusual opportunity to compare compressional- and shear-wave velocities determined under in-situ conditions at a variety of scales of investigation. To facilitate such a comparison, shear-wave velocities were measured on 12 samples from Hole $418 \mathrm{~A}$ at hydrostatic confining pressures ranging from 0.1 to $2.0 \mathrm{kbar}$. These data, plus compressional-wave velocities measured after Legs 51-53 in the same laboratory on these and other samples from Hole 418A, are presented in Table 8 and plotted vs. depth in Figure 14 at an estimated differential confining pressure of $0.1 \mathrm{kbar}$. From this figure it is clear that the compressional- and shear-wave velocities of the rocks themselves increase steadily with depth at rates of

$$
\begin{aligned}
& \mathrm{V}_{p}=1.91 \mathrm{z}+5.25 \\
& \mathrm{~V}_{s}=2.00 \mathrm{z}+2.56,
\end{aligned}
$$

where velocities are in $\mathrm{km} / \mathrm{s}$ and $\mathrm{z}$ is the depth in $\mathrm{km}$. Although the trends are clear, it should be pointed out that the values of $\mathrm{V}_{p}$ and $\mathrm{V}_{s}$ will be higher if lithostatic or hydrostatic conditions prevail. Figure 15 shows, however, that the range of possible velocities for any given sample is small for the range of pressure conditions possible at Site $418\left(\mathrm{P}=\mathrm{P}_{\text {differential }}\right.$ to $\mathrm{P}_{\text {hydrostatic }}$; i.e., $\mathrm{P}=0.1$ to $1.0 \mathrm{kbar}$ ).

It becomes clear from cross-plotting $\mathrm{V}_{p}$ and $\mathrm{V}_{s}$ values determined from multichannel sonic logging (Fig. 16), instead of cross-plotting laboratory values of compressional-wave velocity against shear-wave velocity, that the major lithologies encountered in the upper levels of the crust occupy distinct formation velocity $\left(\mathrm{V}_{p}-\mathrm{V}_{s}\right)$ fields: the massive basalt units cluster around 6.0 and $3.4 \mathrm{~km} / \mathrm{s}$ for $\mathrm{V}_{p}$ and $\mathrm{V}_{s}$, respectively; breccias cluster at the low end of the velocity spectrum $(4.6$ and $2.5 \mathrm{~km} / \mathrm{s}$, respectively); and pillow basalts occupy a broad field in between. Thus, logging velocities can be used to distinguish rock type. Furthermore, because the matrix petrology is (almost) invariant, the velocity trajectories are controlled by porosity. Formation porosity can be determined from velocity from the relation

$$
\phi=95.6-15.4 \mathrm{~V}_{p},
$$

where $\phi$ is in $\%$ and $V_{p}$ is in $\mathrm{km} / \mathrm{s}$ (Broglia and Moos, this volume).

What is more surprising, however, is that the ranges and trajectories of compressional- and shear-wave velocities determined from laboratory studies, logging, and seismic experiments at Site 418 coincide (Fig. 16), a phenomenon that we attribute to the disappearance of low aspect ratio cracks in old crust. Although the ranges of velocities determined at different scales of investigation may coincide, it is nonetheless clear from Figures 10 and 16 and Table 9 that the averages do not. Because the velocities decrease with increasing scale of investigation for the same propagation directions, some cracks remain at all scales even though Layer $2 \mathrm{~A}$ is absent.

\section{ALTERATION}

On Legs 51-53, it was recognized from whole-rock geochemical analyses of representative core samples that the upper levels of the basement at Sites 417 and 418 were strongly altered, with $\mathrm{K}_{2} \mathrm{O}$ averaging $0.5 \%$ (Fig. 17; Flower et al., 1980) in Unit 5 and Subunit $6 \mathrm{~A}$, a value qualitatively confirmed by logging on Leg 102. From thin-section, scanning electron microscope (SEM), and X-ray diffraction (XRD) analysis, Humphris et al. (1980), Pritchard (1980), Pertsev and Rusinov (1980), and Holmes (this volume) have demonstrated that the increase in $\mathrm{K}$ is associated with the presence of alteration products, with about $40 \%$ of the natural gamma-ray count being due to potassium feldspar, $25 \%$ $50 \%$ to palagonite, and $10 \%-33 \%$ to K-rich clays; thus, the rock in these units consists of approximately $24 \% \mathrm{~K}$-spar, $25 \%$ palagonite, and $3 \% \mathrm{~K}$-rich clay $(10 \%$ in the breccias of Subunit $6 \mathrm{~A})$. Assuming that the $\mathrm{K}$ resides largely in clay and that all of the alteration products now observed fill pre-existing voids (fractures, interpillow voids), Broglia and Moos (this volume) estimated that the average original porosity of the upper levels of the crust at Site 418 was as much as $40 \%$. From equation 4 , this implies that the velocity, $\mathrm{V}_{p}$, of the upper crust before alteration 

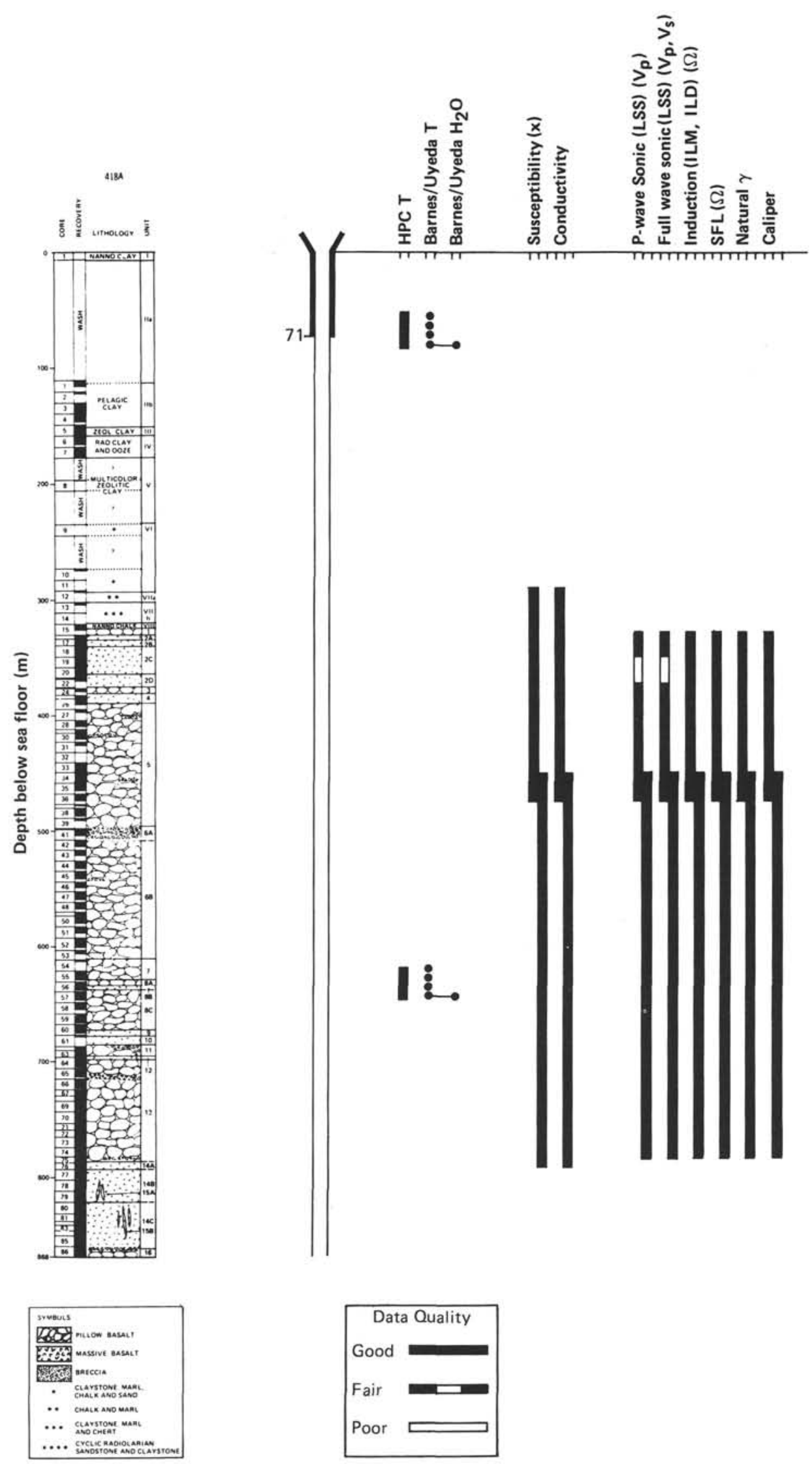

Figure 2. Leg 102 downhole operations summary, Hole 418A (Shipboard Scientific Party, 1986). 
OLD OCEANIC CRUST: SYNTHESIS OF DATA

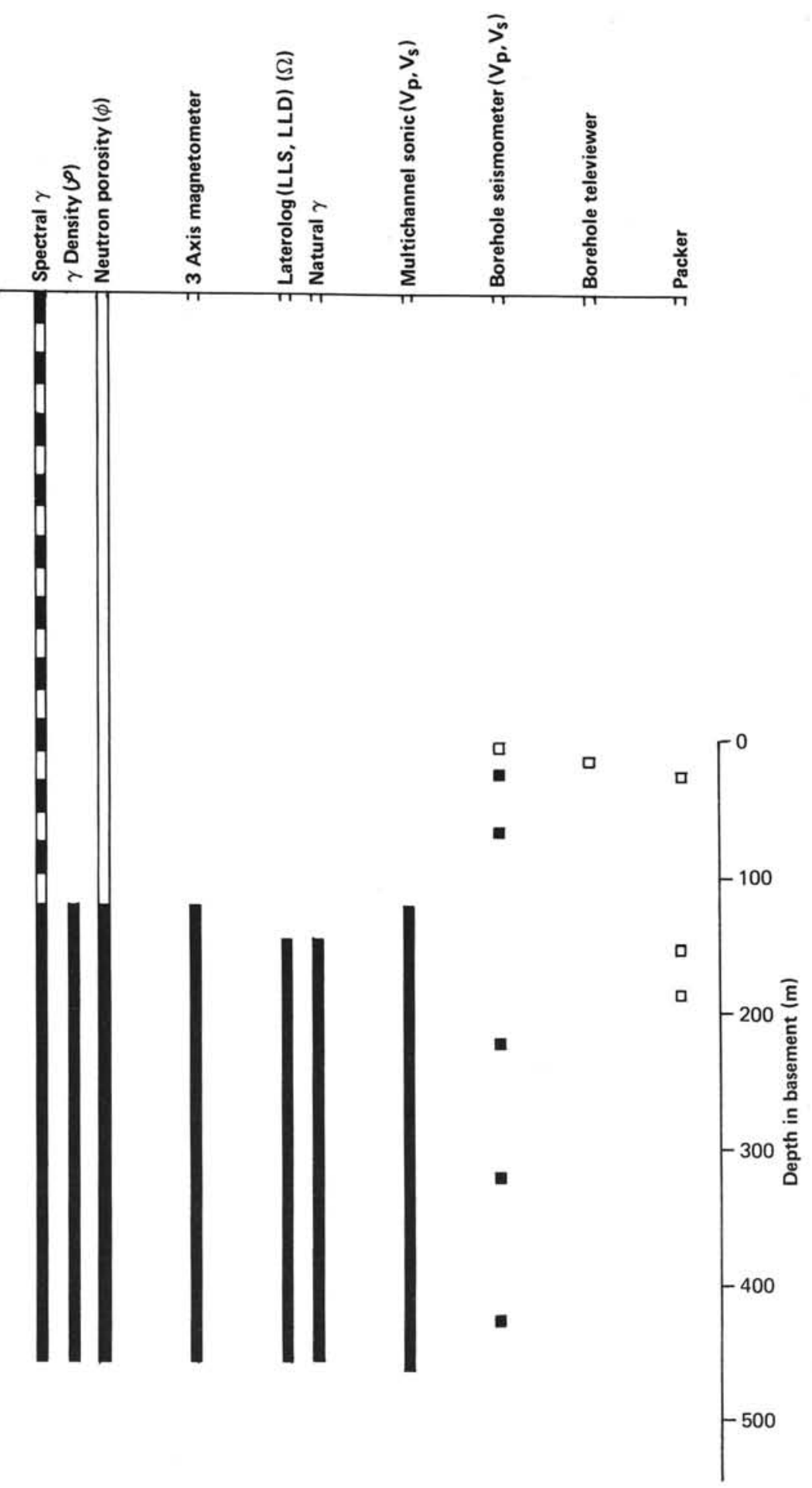

Figure 2 (continued). 
Table 4. Leg 102 downhole operations summary, Hole 418A (Shipboard Scientific Party, 1986).

\begin{tabular}{|c|c|c|c|c|c|c|c|c|c|}
\hline \multirow[b]{2}{*}{ Run } & \multirow[b]{2}{*}{ Date } & \multirow[b]{2}{*}{$\begin{array}{l}\text { Time } \\
\text { (hr) }\end{array}$} & \multicolumn{3}{|c|}{ Depth } & \multirow[b]{2}{*}{$\begin{array}{l}\text { Logging } \\
\text { direction }\end{array}$} & \multirow[b]{2}{*}{ Tool/test } & \multirow[b]{2}{*}{$\begin{array}{c}\text { Data } \\
\text { quality }\end{array}$} & \multirow[b]{2}{*}{ Remarks } \\
\hline & & & $\begin{array}{l}\text { below } \\
\text { rig floor } \\
\text { (m) }\end{array}$ & $\begin{array}{c}\text { below } \\
\text { seafloor } \\
(\mathrm{m})\end{array}$ & $\begin{array}{c}\text { in } \\
\text { basement } \\
\text { (m) }\end{array}$ & & & & \\
\hline
\end{tabular}

HPC temperature probe-Barnes/Uyeda temperature probe-water sampler

$\begin{array}{llllllll}1 & 3 / 24 / 85 & 2145-2400 & { }^{a} 5571-5600 & 52-81 & - & \text { Down } & \begin{array}{l}\text { HPC temperature } \\ \text { Uyeda temperature }\end{array} \\ 2 & 3 / 25 / 85 & 0000-0300 & & & & & \begin{array}{l}\text { Barnes water sampler } \\ \text { HPC temperature }\end{array} \\ \text { Uyeda temperature } \\ \text { Barnes water sampler }\end{array}$

Good

Good

Good

Good

Good

Good Sampled at 649 mbsf

USGS magnetic susceptibility tool

$\begin{array}{lll}3 / 26 / 85 & 1625-2400 \\ 3 / 27 / 85 & 0000-0320\end{array}$

$321-480$

$\begin{array}{ll}0-12 & \text { Down } \\ 0-156 & \text { Down, up }\end{array}$

Susceptibility

Conductivity

Susceptibility

Conductivity

Downhole logging

$13 / 27 / 8$

$3 / 27 / 85$

(1)

$327-480$

3-156

Up

$$
3 / 28 / 85
$$

0330-111

b5968-6298

458-788

134-46

$134-464$

Down, up

Vp

Son

ILM

ILD

SFL

Calipe

Vp

Sonic waveform

ILM

ILD

SFL

$\gamma$

Caliper

$3 \quad 3 / 28 / 85 \quad 1115-2100$

${ }^{5} 510-5972$
$5972-6300$
$5510-5972$
$5972-6300$
$5510-5972$
$5972-6300$

0-462

462-790

0-462

462-790

0-462

462-790

0-138

138-466

$0-138$

138-466 Down, up

0-138 Up

Spectral $\gamma$

$\gamma$-density

Neutron porosity

138-466

Down, up

German three-axis magnetometer

$1 \quad 3 / 28 / 85 \quad 2100-2400$

$3 / 29 / 85 \quad 2400-1500$

$465-790$

$141-466$

Down, up

$\mathrm{H}_{\mathrm{x}, \mathrm{y}, \mathrm{z}}$

Good

Downhole logging

$4 \quad 3 / 29 / 85 \quad 1500-2345$

$b_{6000-6295}$

490-785

$166-461$

Up

$\Omega$ Laterolog LLS

LLD

Good

Fair

LDGO multichannel sonic tool

$1 \quad 3 / 30 / 85 \quad 0100-0745$

USGS magnetic susceptibility tool

$$
3 \quad 3 / 30 / 85 \quad 0745-1600
$$

$$
\mathrm{b}_{5875-6310}
$$

$365-800$

$41-476$

Down, up

$\mathrm{Vp}, \mathrm{V}_{\mathrm{s}}$

Good

$b_{5975-6310}$

465-800

$141-476$

Down, up

Susceptibility Conductivity

Good

Poor

Tool temperature too low (down only)

WHOI borehole seismometer

$13 / 30 / 85$

$3 / 31 / 85 \quad 0000-2400$

$4 / 1 / 85 \quad 0000-2400$

$4 / 2 / 85 \quad 0000-2400$

$4 / 3 / 85 \quad 0000-2400$

$4 / 4 / 85 \quad 0000-0430$

626

555,655 ,

755

230,33

Stationary

Vp, Vsv, Vsh

Anisotropy

Good

$5853,5876, \quad 343,366$,

18,41

Stationary

Evanescent waves

406

81

Packer

$1 \quad 4 / 6 / 85$

$$
\begin{aligned}
& 4 / 6 / 85 \\
& 4 / 7 / 85
\end{aligned}
$$

1625-2400

0000-0930

$\begin{array}{ll}b_{5867,} 5985, & 347,465, \\ 6037 & 517\end{array}$

23,14

Stationary

Pore pressure,

permeability $\begin{array}{lc}\text { Good } & \text { Tool temperature too } \\ \text { Poor } & \text { low } \\ \text { Good } & \text { Tool temperature too } \\ \text { Poor } & \text { low (down only) }\end{array}$

Through pipe

\begin{tabular}{|c|c|c|c|c|c|c|c|c|c|}
\hline 1 & $4 / 7 / 85$ & $1200-2300$ & $\mathrm{~b}_{5870}$ & 360 & 36 & Down & $\begin{array}{l}\text { Borehole imagery } \\
\text { Acoustic caliper }\end{array}$ & $\begin{array}{l}\text { Fair } \\
\text { Fair }\end{array}$ & $\begin{array}{l}\text { Slow sweep; tool } \\
\text { caught on ledge }\end{array}$ \\
\hline
\end{tabular}

Through pipe

Through pipe

LDGO borehole televiewer

a Subtract $10 \mathrm{~m}$ to obtain depth below sea level.

${ }^{b}$ Equals depth below sea level (rig floor height and cable stretch cancel each other, by coincidence). 


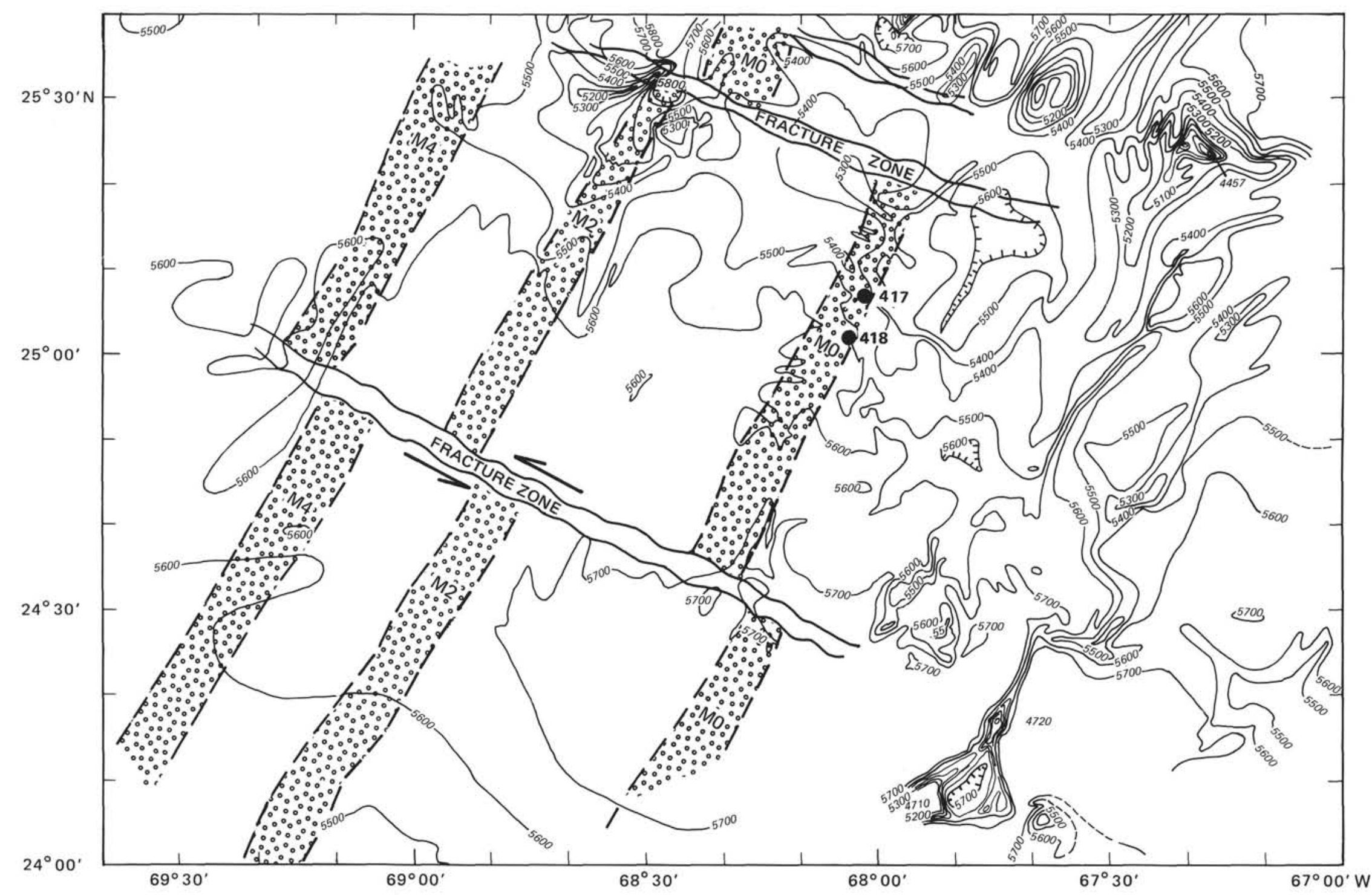

Figure 3. Bathymetry and positions of magnetic source bodies near Sites 417 and 418 (Rabinowitz et al., 1980). Depths contoured in 100-m intervals. 


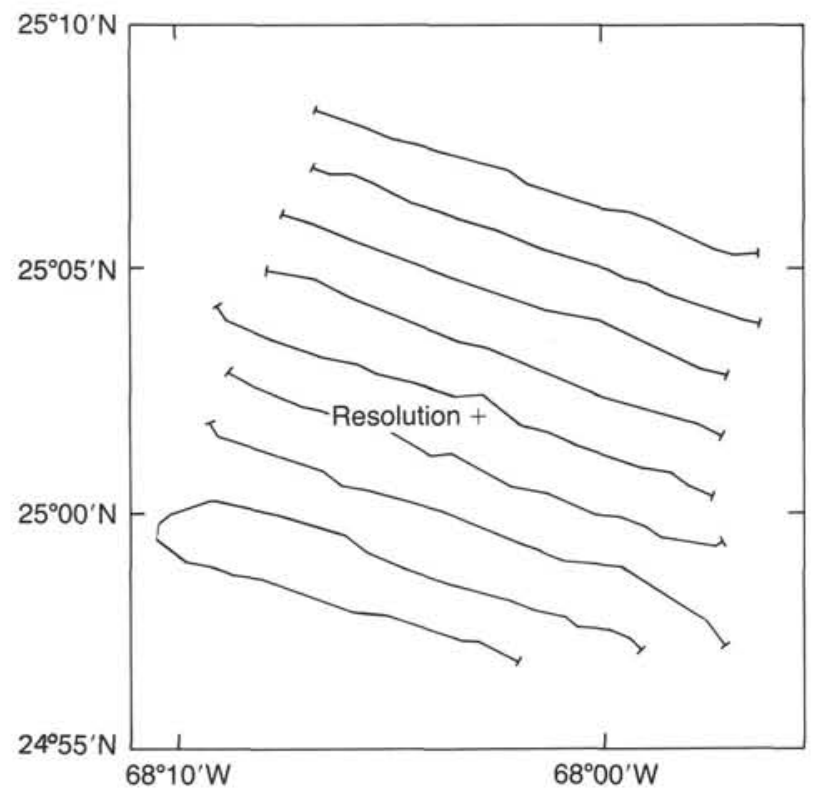

Figure 4. Location of seismic reflection lines run by R/V Fred $H$. Moore during Leg 102.

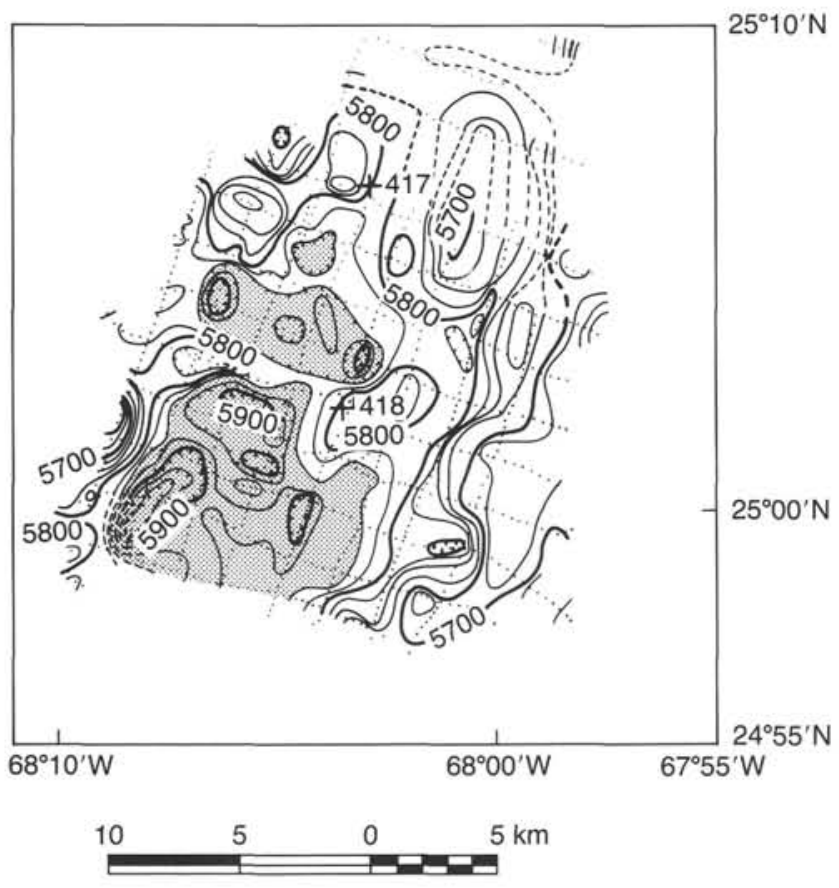

Figure 5. Basement topography showing valley (stippled) near Sites 417 and 418 (crosses). Contours in $25-\mathrm{m}$ intervals. Figure after Senske and Stephen (this volume).

was less than $3.5 \mathrm{~km} / \mathrm{s}$ (Fig. 18) (i.e., that Layer $2 \mathrm{~A}$ was present when this crust resided at the ridge crest). Although the estimates of original porosity and velocity are only qualitative (if some of the $\mathrm{K}$ resides in $\mathrm{K}$-spar, the original large-scale porosity would be lower; if K-poor alteration products such as calcite, quartz, and K-poor clays are abundant, the porosity was higher), they nonetheless appear to be approximately correct.

If infilling has occurred on the scale implied by the logging data, it should be observable in the core. This is indeed the case:

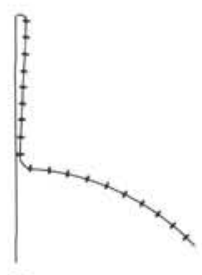

$41 \mathrm{~m}$

$81 \mathrm{~m}$

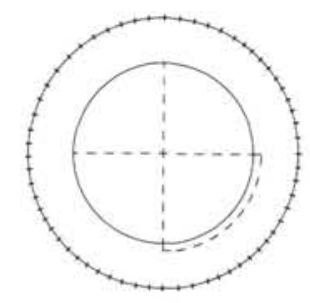

$230 \mathrm{~m}$

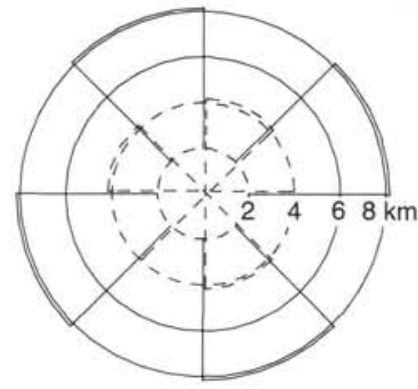

$330 \mathrm{~m}$
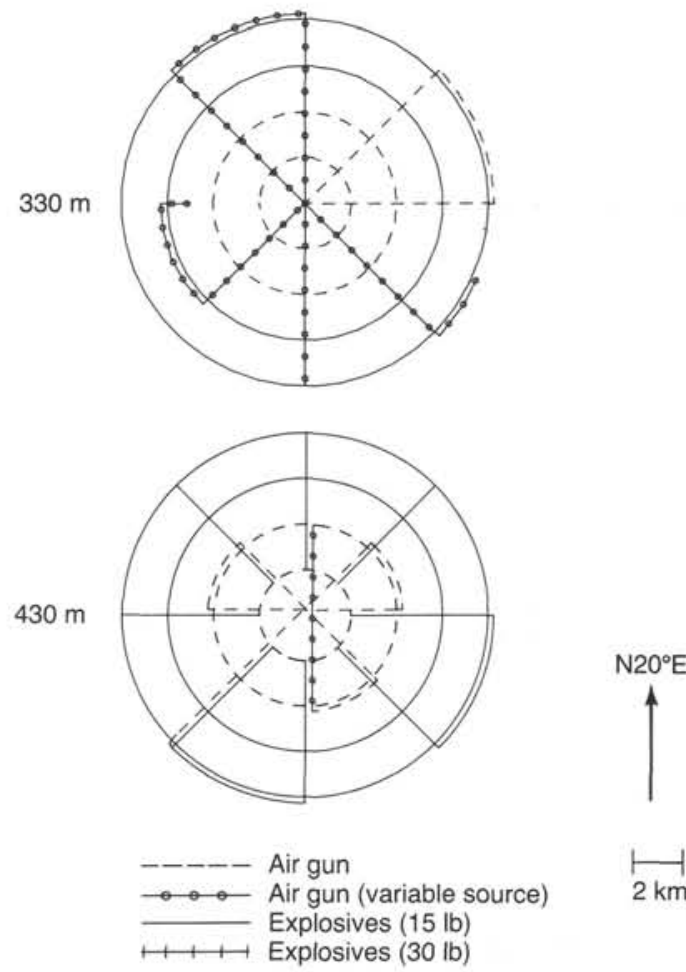

$\frac{1}{2 \mathrm{~km}}$

Figure 6. Air gun and explosive shooting patterns conducted in the vicinity of the JOIDES Resolution during oblique seismic experiment. Seismometer clamp points given in $\mathrm{m}$ within the basement for each shot pattern. Figure after Shipboard Scientific Party (1986). 


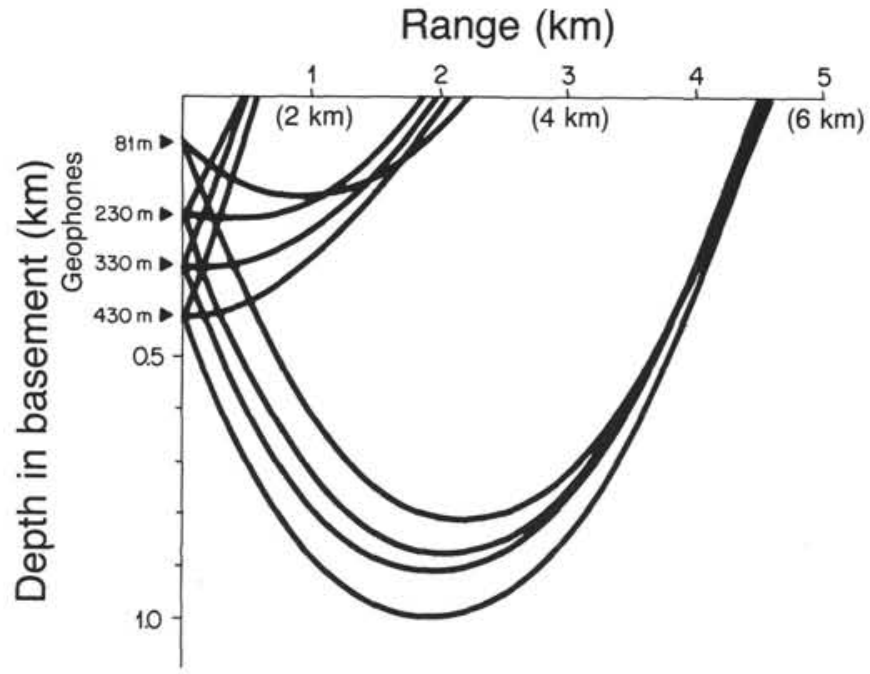

Figure 7. Typical ray paths in basement for circular shooting patterns with 2-, 4-, and 6-km radii. 4:1 vertical exaggeration.

\begin{tabular}{|c|c|}
\hline $\begin{array}{l}\text { Depth in } \\
\text { basement } \\
\text { (m) }\end{array}$ & $\begin{array}{c}\mathrm{V}_{p} \\
(\mathrm{~km} / \mathrm{s})\end{array}$ \\
\hline $0-81$ & - \\
\hline $81-230$ & 4.6 \\
\hline $230-330$ & 4.5 \\
\hline \multirow{2}{*}{$330-430$} & 4.8 \\
\hline & 4.6 \\
\hline
\end{tabular}

Table 5B. Inflection point velocities from fits to radial line data (after Swift and Stephen, this volume).

\begin{tabular}{clccc}
\hline $\begin{array}{c}\text { Depth in } \\
\text { basement } \\
(\mathrm{m})\end{array}$ & Data processing & $\begin{array}{c}\text { Number } \\
\text { of shots }\end{array}$ & $\begin{array}{c}\text { Inflection } \\
\text { point } \\
\text { range }(\mathrm{km})\end{array}$ & $\begin{array}{c}\mathrm{V}_{p} \\
(\mathrm{~km} / \mathrm{s})\end{array}$ \\
\hline 41 & Before reduction & 24 & 2.43 & 4.71 \\
& After reduction & 24 & - & 5.09 \\
81 & Before reduction & 119 & 3.18 & 4.63 \\
& After reduction & - & - & $-\overline{-}$ \\
230 & Before reduction & 294 & 3.95 & 4.92 \\
& After reduction & 302 & 2.45 & 4.67 \\
330 & Before reduction & 245 & 3.73 & 4.93 \\
& After reduction & 284 & 2.35 & 4.59 \\
430 & Before reduction & 305 & 4.55 & 5.03 \\
& After reduction & 305 & 2.59 & 4.79 \\
\hline
\end{tabular}

breccias are typically sealed with clays, interpillow voids with palagonite, and veins and vesicles with ordered sequences of oxides, clays, pyrite, and calcite (Pl. 1; Shipboard Scientific Parties, 1980a, 1980b). On the basis of SEM and XRD transects across these sequences, Holmes (this volume) concluded that the alteration products evolved continuously in a closed system. The first stage of alteration involved oxidation and the precipitation of Fe oxide-hydroxides on the walls of veins and vesicles. This was followed in turn by the precipitation of K-rich clays (celadonite, celadonite/nontronite, or K-rich nontronite) from the least-evolved fluid; by increasingly $\mathrm{K}$-poor, $\mathrm{Mg}$-rich clays and eventually saponite and pyrite as the pore fluid evolved from a $\mathrm{K}$ - and $\mathrm{Fe}^{3+}$-rich to a $\mathrm{K}$-poor, $\mathrm{Mg}$-, $\mathrm{Fe}^{2+}-, \mathrm{Al}-$, and $\mathrm{Ca}$ -
Table 5C. Results of $\tau-\zeta$ inversion (after Swift and Stephen, this volume).

\begin{tabular}{lcc}
\hline $\begin{array}{c}\text { Depth in } \\
\text { basement } \\
(\mathrm{km})\end{array}$ & $\begin{array}{c}\mathrm{V}_{p} \\
(\mathrm{~km} / \mathrm{s})\end{array}$ & $\mathrm{V}_{s}=0.55 \mathrm{~V}_{p}$ \\
$(\mathrm{~km} / \mathrm{s})$
\end{tabular}

rich fluid; and, eventually, by calcite as the $\mathrm{CO}_{2}$ level increased. In the upper levels of the section (Unit 5 and Subunit 6A) and parts of Subunits/Units 8B-13A, a second oxidizing stage, initiated perhaps by off-axis faulting, caused saponite to alter to iddingsite, releasing silica, and plagioclase to alter to K-spar, releasing $\mathrm{Ca}$. The products of this last stage of alteration thus include Fe oxide-hydroxides, iddingsite, K-spar, quartz, and calcite.

The final consequences of the alteration processes described in this section would be a change from convective to conductive heat flow in response to decreasing permeability and an equilibrium pore-fluid chemistry showing a marked enrichment in $\mathrm{Ca}$ and $\mathrm{Si}$ and a depletion in $\mathrm{K}$ with respect to seawater. These predictions were confirmed by borehole temperature and pore-fluid chemistry measurements conducted during Leg 102 (Shipboard Scientific Party, 1986; Gieskes et al., this volume).

\section{CONCLUSIONS}

Upon the completion of drilling operations at Sites 417 and 418 on Legs 51-53, it was concluded that the properties of old oceanic crust were very different from young crust because of alteration and infilling of void space with age. Because these conclusions were based on a suite of geophysical logs that was limited to the upper $93 \mathrm{~m}$ of basement in Hole 417D, plus visual and laboratory studies of the core, they could only be regarded as tentative.

On Leg 102 , Hole 418 A, the deepest of the holes originally drilled in the area, was reentered and logged to a depth of 0.5 $\mathrm{km}$ into the basement using an extensive suite of state-of-the-art logging tools. The original conclusions were confirmed and a number of important findings were made concerning the geophysical properties of old oceanic crust:

1. Layer $2 \mathrm{~A}$ is absent. From the results of the OSE at Site 418 , it is clear that $V_{p}$ increases gradually from $4.5 \mathrm{~km} / \mathrm{s}$ at the top of the basement to velocities typical of Layer $3(6.9 \mathrm{~km} / \mathrm{s})$ at a depth of $1.5 \mathrm{~km}$ within the basement, whereas $\mathrm{V}_{s}$ increases from 2.4 to $3.7 \mathrm{~km} / \mathrm{s}$ over the same interval.

2. The upper $0.5 \mathrm{~km}$ of the crust displays azimuthal anisotropy to a range of about $0.6 \mathrm{~km}$. $\mathrm{V}_{p}$ varies with azimuth by $\pm 0.2 \mathrm{~km} / \mathrm{s}$, with the fast direction lying parallel to spreading in the upper levels of the crust but rotating counterclockwise with depth until it is subperpendicular to spreading at a depth of about $0.5 \mathrm{~km}$.

3. The upper $0.5 \mathrm{~km}$ of the crust displays vertical/horizontal anisotropy with $\mathrm{V}_{p}$ fast in the horizontal direction $(4.8 \mathrm{~km} / \mathrm{s}$ by $\tau-\zeta$ and inflection point analysis) and slow in the vertical direction $(4.6 \mathrm{~km} / \mathrm{s}$ by VSP analysis).

4. Although less pervasively cracked than young crust, the upper $0.5 \mathrm{~km}$ of the basement at Site 418 is nonetheless cracked at all scales of investigation. This is a necessary consequence of the preceding three conclusions, and the fact that the average compressional-wave velocity of samples from this interval (5.7 $\mathrm{km} / \mathrm{s}$ ) is greater than the interval velocity determined from logs $(5.1 \mathrm{~km} / \mathrm{s})$, which, in turn, is greater than that determined from 


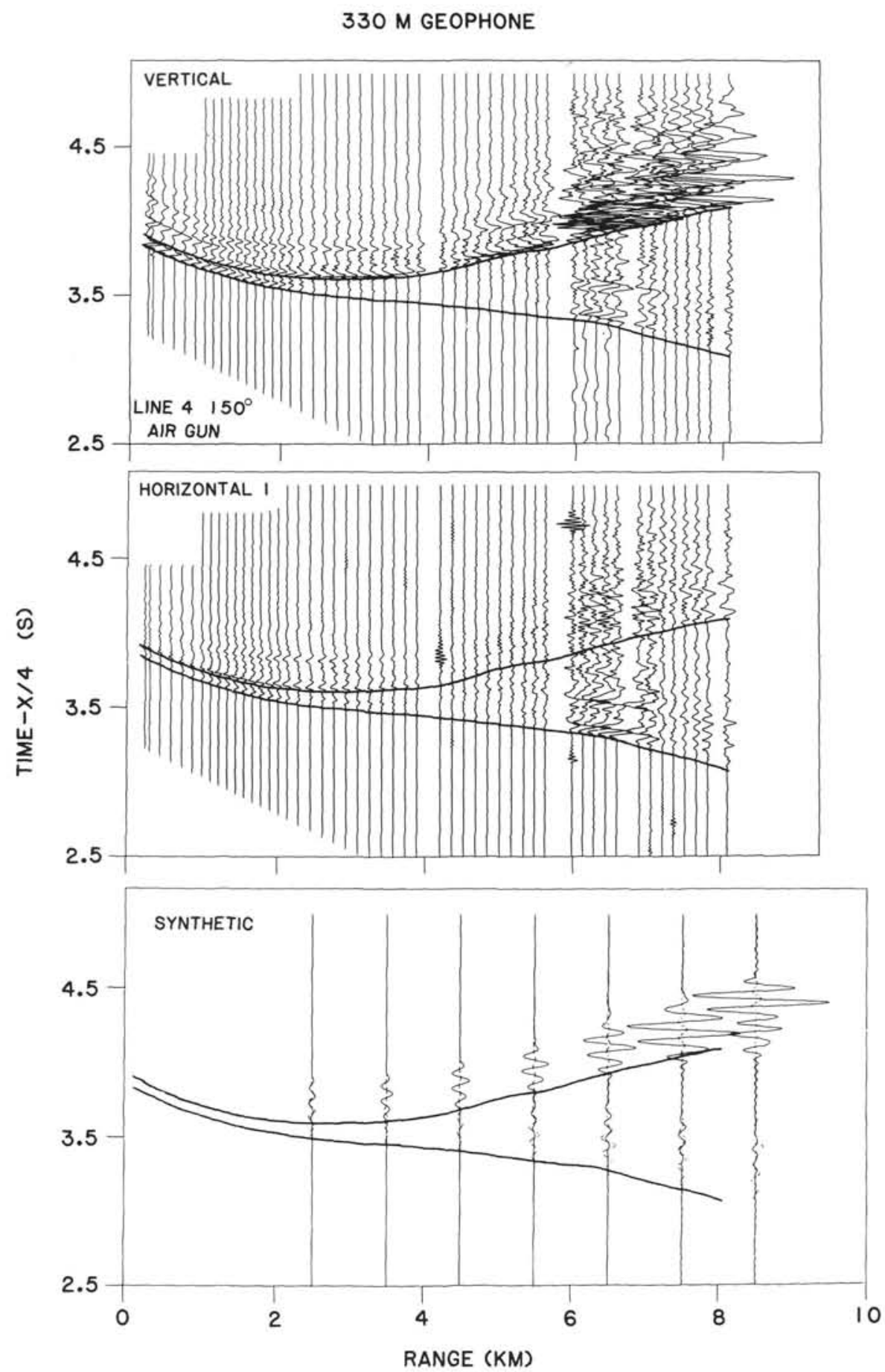

Figure 8. Comparison of traveltime and amplitude vs. range data for shot line 4 with the seismometer clamped $330-\mathrm{m}$ within the basement and synthetic seismograms generated for the same line, assuming $\mathrm{V}_{s}=0.55 \mathrm{~V}_{p}$. Synthetic vertical component is solid, horizontal is dashed. Observed seismograms corrected for geometric spreading and band-pass filtered at $5-50 \mathrm{~Hz}$.

the OSE ( 4.6 to $5.0 \mathrm{~km} / \mathrm{s}$, depending on the propagation direction).

5. On average, the upper $0.5 \mathrm{~km}$ of the crust at Site 418 now consists of about $86 \%$ basalt, $9 \%$ palagonite and clay, and $5 \%$ open cracks filled with water. Of the basalts, $69 \%$ consist of pillow basalts, $27 \%$ are massive basalts, and $4 \%$ consist of cemented basalt breccias. The basalts themselves contain considerable primary (vesicular and grain boundary) porosity, bringing the total formation porosity to $15 \%$.
6. The upper levels of the section (Unit 5 and Subunit 6A) display a higher total porosity ( $20 \%$, of which $14 \%$ is primary porosity and $6 \%$ is fracture porosity) and a much higher clay content $(19 \%)$ than the section as a whole. From the original core descriptions, it is clear that most of the alteration products fill pre-existing interpillow voids and fractures. Thus, the original formation porosity was about $40 \%$, much higher than it is now. Velocity-porosity systematics based on logs demonstrate that the compressional-wave velocity of this level of the crust 


\section{KM CIRCLE}
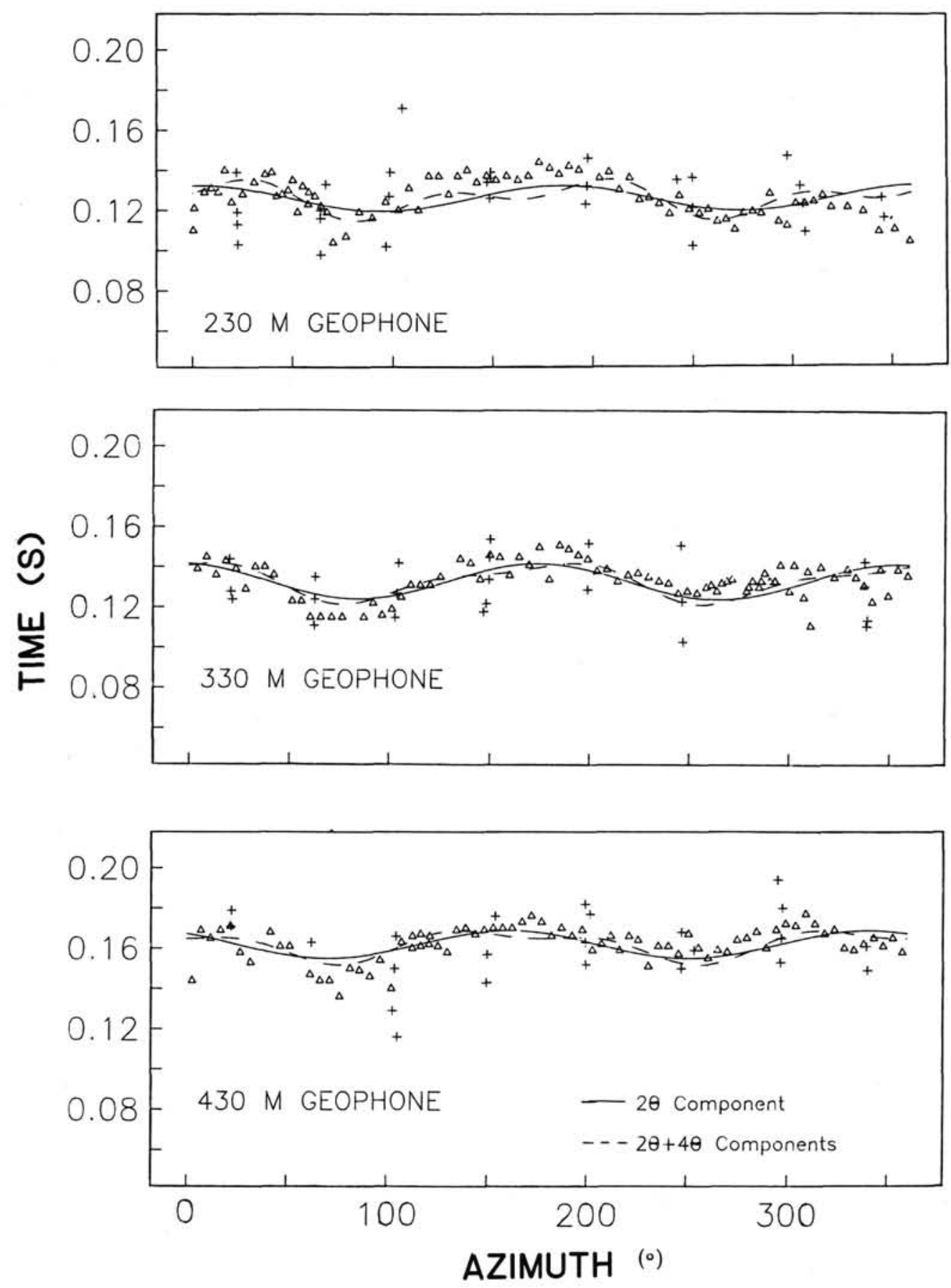

Figure 9. $P$-wave traveltimes vs. azimuth to shot points on $2-\mathrm{km}$ circle (triangles) for various seismometer depths. Crosses represent arrivals from shots on radial lines within $0.3 \mathrm{~km}$ of circle. $2 \theta$ and $4 \theta$ components represent variations with $180^{\circ}$ and $90^{\circ}$ periodicities, respectively.

prior to infilling (i.e., when it resided at the ridge crest) was about $3.5 \mathrm{~km} / \mathrm{s}$, equivalent to that of Layer $2 \mathrm{~A}$.

7. The disappearance of Layer $2 \mathrm{~A}$ and the pronounced changes in geophysical properties that occur with age in the upper levels of the crust are due to the infilling of voids and cracks by secondary minerals formed by rock-seawater interaction. The sequence at Site 418 is ordered and continuous, starting with Fe oxide-hydroxides and proceeding through K-rich to K-poor clays, pyrite, and finally calcite, suggesting evolution in a closed system. Because similar sequences are observed in other ODP holes, we conclude that the aging phenomena documented at Site 418 are widespread in old oceanic crust.

\section{ACKNOWLEDGMENTS}

We wish to thank the Captains and crews of the JOIDES Resolution and the R/V Fred H. Moore for their assistance during the logging and 


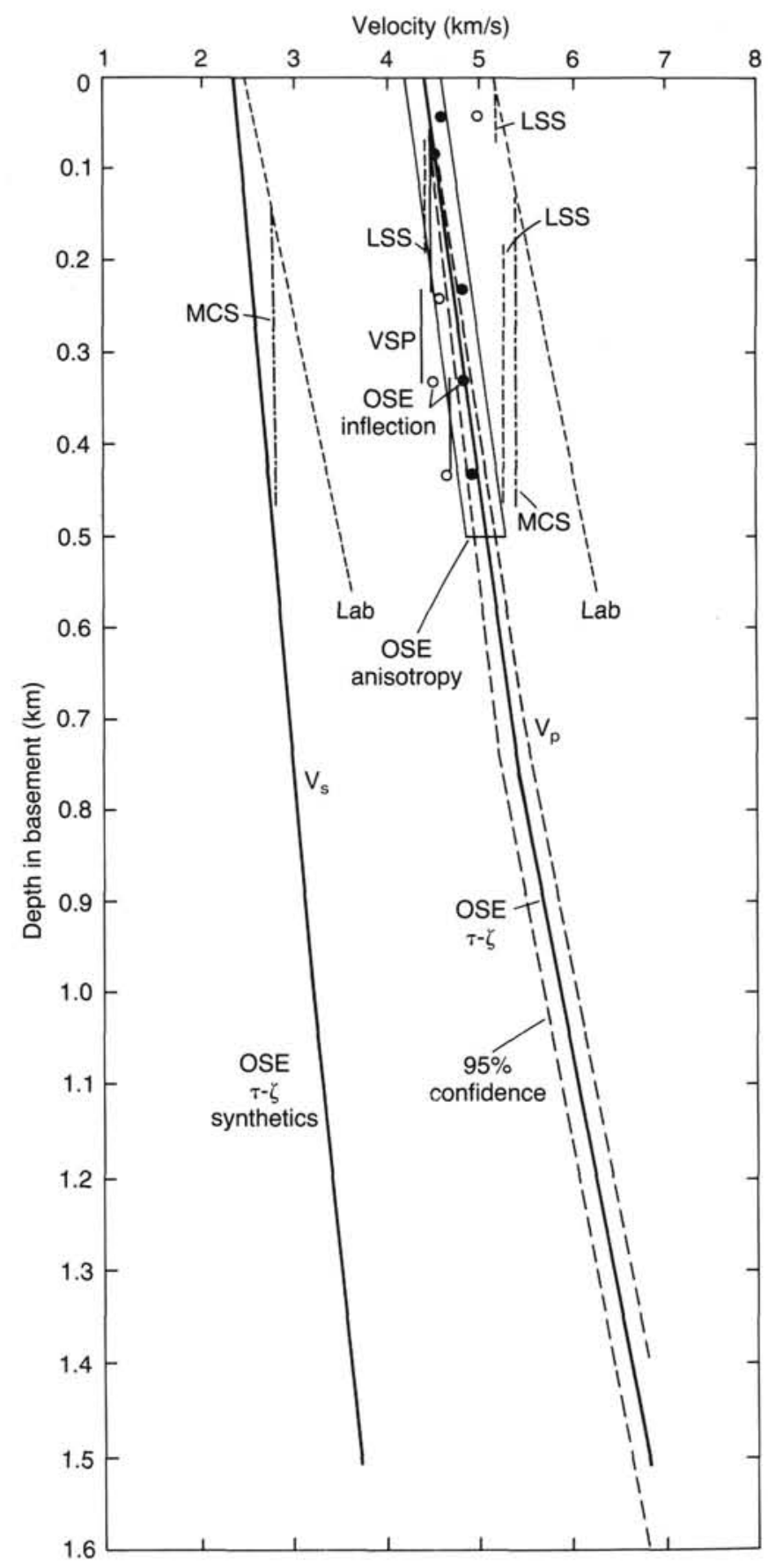

Figure 10. Comparison of compressional- and shear-wave velocities obtained in Hole 418A from laboratory studies, logging, and the oblique seismic experiment (OSE). Laboratory $\mathrm{V}_{p}$ and $\mathrm{V}_{s}$ trends represent leastsquares fits to data obtained at a differential confining pressure of 0.1 kbar. Multichannel sonic (MCS) logging data from Moos (this volume); long-spaced sonic (LSS) data from Broglia and Moos (this volume). OSE data (VSP, inflection, $\tau-\zeta$, anisotropy) from Swift and Stephen (this volume); solid and open circles represent inflection point data before and after reduction to basement, respectively.

OSE; Glen Foss and Bob Caldow for their careful orchestration of rigfloor operations; Jeff Skelly of Schlumberger, Ltd., and Ewald Meyer of BGR for running the logs; Michael Reitmeyer, Daniel Larson, Patrick Thompson, and Warren Witzell for preparing and maintaining the tools; and Mark Weiderspahn and William Robinson for preparing and writing the digital acquisition system for the borehole seismometer experiment.
This study was supported by grants to R. A. Stephen from the U.S. National Science Foundation in support of the OSE (OCE-8416633), to M. H. Salisbury from Petro-Canada and the Natural Sciences and Engineering Research Council in support of logging research (IRC 8403), and to N. I. Christensen from the U.S. Navy in support of laboratory velocity studies (ONR Contract N-0001 4-84-K-0207). Grants from the U.S. Scientific Advisory Committee to the U.S. participants on the JOIDES Resolution supported participation on Leg 102 and post-cruise data analysis.

\section{REFERENCES}

Christensen, N. I., Blair, S. C., Wilkens, R. H., and Salisbury, M. H., 1980. Compressional wave velocities, densities and porosities of basalts from Holes 417A, 417D and 418A, Deep Sea Drilling Project Legs 51 through 53. In Donnelly, T., Francheteau, J., Bryan, W., Robinson, P., Flower, M., Salisbury, M., et al., Init. Repts. DSDP, 51, 52, 53, Pt. 2: Washington (U.S. Govt. Printing Office), 14671472.

Donnelly, T., Thompson, G., and Salisbury, M., 1980. The chemistry of altered basalts at Site 417, Deep Sea Drilling Project Leg 51. In Donnelly, T., Francheteau, J., Bryan, W., Robinson, P., Flower, M., Salisbury, M., et al., Init. Repts. DSDP, 51, 52, 53, Pt. 2: Washington (U.S. Govt. Printing Office), 1319-1330.

Dorman, L. M., and Jacobson, R. S., 1981. Linear inversion of body wave data, Part 1: Velocity structure from travel times and ranges. Geophysics, 46:138-151.

Flower, M., Ohnmacht, W., Robinson, P., Marriner, G. and Schminke, H.-U., 1980. Lithologic and chemical stratigraphy at Deep Sea Drilling Project Sites 417 and 418. In Donnelly, T., Francheteau, J., Bryan, W., Robinson, P., Flower, M., Salisbury, M., et al., Init. Repts. DSDP, 51, 52, 53, Pt. 2: Washington (U.S. Govt. Printing Office), 939-956.

Fuchs, K., and Müller, G., 1971. Computation of synthetic seismograms with the reflectivity method and comparison with observations. Geophys. J. R. Astron. Soc., 23:417-433.

Hamano, Y., 1980. Physical properties of basalts from Holes 417D and 418A. In Donnelly, T., Francheteau, J., Bryan, W., Robinson, P., Flower, M., Salisbury, M., et al., Init. Repts. DSDP, 51, 52, 53, Pt. 2: Washington (U.S. Govt. Printing Office), 1457-1466.

Houtz, R., and Ewing, J., 1976. Upper crustal structure as a function of plate age. J. Geophys. Res., 81:2490-2498.

Humphris, S. E., Thompson, R. N., and Marriner, G. F., 1980. The mineralogy and geochemistry or basalt weathering, Holes $417 \mathrm{~A}$ and 418A. In Donnelly, T., Francheteau, J., Bryan, W., Robinson, P., Flower, M., Salisbury, M., et al., Init. Repts. DSDP, 51, 52, 53, Pt. 2: Washington (U.S. Govt. Printing Office), 1201-1218.

Hyndman, R. D., Salisbury, M. H., et al., 1984. Init. Repts. DSDP, 78B: Washington (U.S. Govt. Printing Office).

Johnson, D. M., 1980. Fluid permeability of oceanic basalts. In Donnelly, T., Francheteau, J., Bryan, W., Robinson, P., Flower, M., Salisbury, M., et al., Init. Repts. DSDP, 51, 52, 53, Pt. 2: Washington (U.S. Govt. Printing Office), 1473-1478.

Juteau, T., Noack, Y., Whitechurch, H., and Courtois, C., 1980. Mineralogy and geochemistry of alteration products in Holes 417 A and 417D basement samples (Deep Sea Drilling Project Leg 51). In Donnelly, T., Francheteau, J., Bryan, W., Robinson, P., Flower, M., Salisbury, M., et al., Init. Repts. DSDP, 51, 52, 53, Pt. 2: Washington (U.S. Govt. Printing Office), 1273-1298.

Kirkpatrick, R. J., 1979. Results of downhole geophysical logging Hole 396B, DSDP Leg 46. In Dmitriev, L., Heirtzler, J., et al., Init. Repts. DSDP, 46: Washington (U.S. Govt. Printing Office), 401-408.

Leg 109 Shipboard Scientific Party, 1986. Coring the crust and the mantle. Nature, 323:492-493.

Levi, S., 1980. Paleomagnetism and some magnetic properties of basalts from the Bermuda Triangle. In Donnelly, T., Francheteau, J., Bryan, W., Robinson, P., Flower, M., Salisbury, M., et al., Init. Repts. DSDP, 51, 52, 53, Pt. 2: Washington (U.S. Govt. Printing Office), 1363-1378.

Levi, S., Bleil, U., Smith, B. M., and Rigotti, P., 1980. Compilation of paleomagnetic and rock magnetic results of basalt samples from Deep Sea Drilling Project Legs 51, 52, and 53. In Donnelly, T., Francheteau, J., Bryan, W., Robinson, P., Flower, M., Salisbury. M., et al., Init. Repts. DSDP, 51, 52, 53, Pt. 2: Washington (U.S. Govt. Printing Office), $1337-1350$. 
Newmark, R. L., Anderson, R. N., Moos, D., and Zoback, M. D., 1985. Sonic and ultrasonic logging of Hole 504B and its implications for the structure, porosity and stress regime of the upper $1 \mathrm{~km}$ of the oceanic crust. In Anderson, R. N., Honnorez, J., Becker, K., et al., Init. Repts. DSDP, 83: Washington (U.S. Govt. Printing Office), 479-510.

Pertsev, N. N., and Rusinov, V. L., 1980. Mineral assemblages and processes of alteration in basalts at Deep Sea Drilling Project Sites 417 and 418. In Donnelly, T., Francheteau, J., Bryan, W., Robinson, P., Flower, M. Salisbury, M., et al., Init. Repts. DSDP, 51, 52, 53, Pt. 2: Washington (U.S. Govt. Printing Office), 1219-1242.

Pritchard, R. G., 1980. Alteration of basalts from Deep Sea Drilling Project Legs 51, 52 and 53, Holes 417A and 418A. In Donnelly, T., Francheteau, J., Bryan, W., Robinson, P., Flower, M., Salisbury, M., et al., Init. Repts. DSDP, 51, 52, 53, Pt. 2: Washington: (U.S. Govt. Printing Office), 1185-1200.

Rabinowitz, P. D., Hoskins, H., and Asquith, S. M., 1980. Geophysical site summary results near Deep Sea Drilling Project Sites 417 and 418 in the Central Atlantic Ocean. In Donnelly, T., Francheteau, J., Bryan, W., Robinson, P., Flower, M., Salisbury, M., et al., Init. Repts. DSDP, 51, 52, 53, Pt. 1: Washington (U.S. Govt. Printing Office), 629-669.

Robinson, P. T., Flower, M.F.J., Swanson, D. A., and Staudigel, H. 1980. Lithology and eruptive stratigraphy of Cretaceous oceanic crust, western Atlantic Ocean. In Donnelly, T., Francheteau, J., Bryan, W., Robinson, P., Flower, M., Salisbury, M., et al., Init. Repts. DSDP, 51, 52, 53, Pt. 2: Washington (U.S. Govt. Printing Office), 1535-1555.

Salisbury, M. H., Donnelly, T. W., and Francheteau, J., 1980a. Geophysical logging in Deep Sea Drilling Project Hole 417D. In Donnelly, T., Francheteau, J., Bryan, W., Robinson, P., Flower, M., Salisbury, M., et al., Init. Repts. DSDP, 51, 52, 53, Pt. 1: Washington (U.S. Govt. Printing Office), 705-714.

Salisbury, M. H., Stephen, R., Christensen, N. I., Francheteau, J., Hamano, Y., Hobart, M., and Johnson, D., 1980b. The physical state of the upper levels of Cretaceous oceanic crust from the results of logging, laboratory studies and the oblique seismic experiment at
Deep Sea Drilling Project Sites 417 and 418. In Donnelly, T., Francheteau, J., Bryan, W., Robinson, P., Flower, M., Salisbury, M., et al., Init. Repts. DSDP, 51, 52, 53, Pt. 2: Washington (U.S. Govt. Printing Office), 1579-1597.

Schreiber, E., and Fox, P. J., 1976. Compressional wave velocities and mineralogy of fresh basalts from the FAMOUS area and the Oceanographer Fracture Zone and the texture of Layer 2A of the oceanic crust. J. Geophys. Res., 81:4071-4076.

Shipboard Scientific Parties, 1980a. Site 417. In Donnelly, T., Francheteau, J., Bryan, W., Robinson, P., Flower. M., Salisbury. M., et al., Init. Repts. DSDP, 51, 52. 53, Pt. 1: Washington (U.S. Govt. Printing Office), 23-350.

1980b. Site 418. In Donnelly, T., Francheteau, J., Bryan, W., Robinson, P., Flower, M., Salisbury, M., et al., Init. Repts. DSDP, 51, 52. 53, Pt. 1: Washington (U.S. Govt. Printing Office), 351-626. Shipboard Scientific Party, 1979a. Site $395: 23^{\circ} \mathrm{N}$, Mid-Atlantic Ridge. In Melson, W. G., Rabinowitz, P. D., et al., Init. Repts. DSDP, 45: Washington (U.S. Govt. Printing Office), 131-264. 1979b. Holes 396A and 396B. In Dmitriev, L., Heirtzler, J., et al., Init. Repts. DSDP, 46: Washington (U.S. Govt. Printing Office), $15-86$.

1986. Site 418: Bermuda Rise. In Salisbury, M. H., Scott, J. H., et al., Proc. ODP, Init. Repts., 102: College Station, TX (Ocean Drilling Program), 95-235.

Stephen, R. A., and Harding, A. J., 1983. Travel time analysis of borehole seismic data. J. Geophys. Res., 88:8289-8298.

Stephen, R. A., Louden, K. E., and Mathews, D. H., 1980. The oblique seismic experiment on Deep Sea Drilling Project Leg 52. In Donnelly, T., Francheteau, J., Bryan, W., Robinson, P., Flower, M., Salisbury, M., et al., Init. Repts. DSDP, 51, 52, 53, Pt. 1: Washington (U.S. Govt. Printing Office), 675-704.

Date of initial receipt: 7 July 1987

Date of acceptance: 4 January 1988

Ms 102B-123 


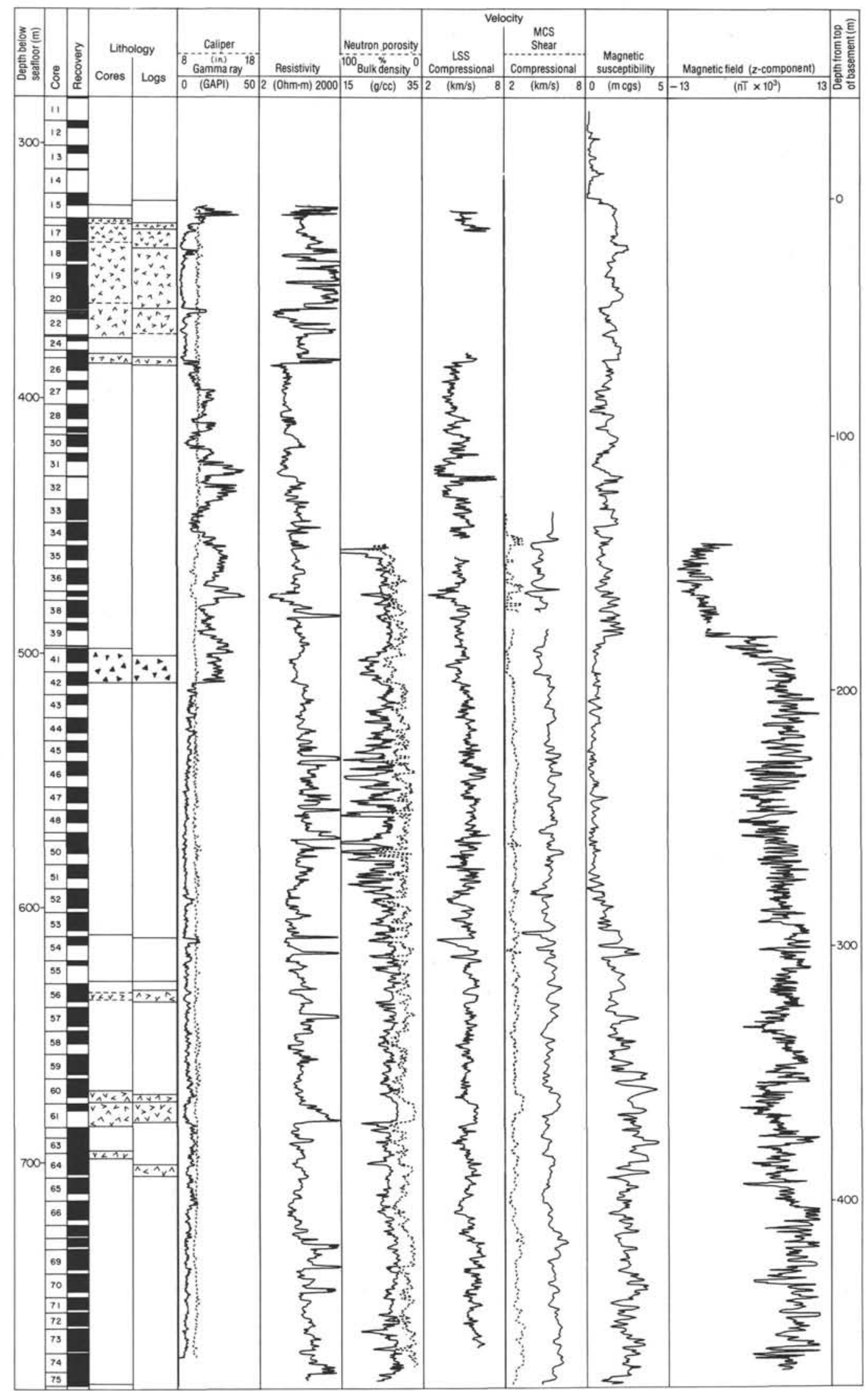

Figure 11. Lithology and logging data obtained in Hole 418A on Leg 102 (Shipboard Scientific Party, 1986). Pillow basalt $=$ no symbol; massive basalt $=$ carets; breccia $=$ triangles. 
Table 6. Properties of basement units in Hole 418A based on well logs (after Shipboard Scientific Party, 1986).

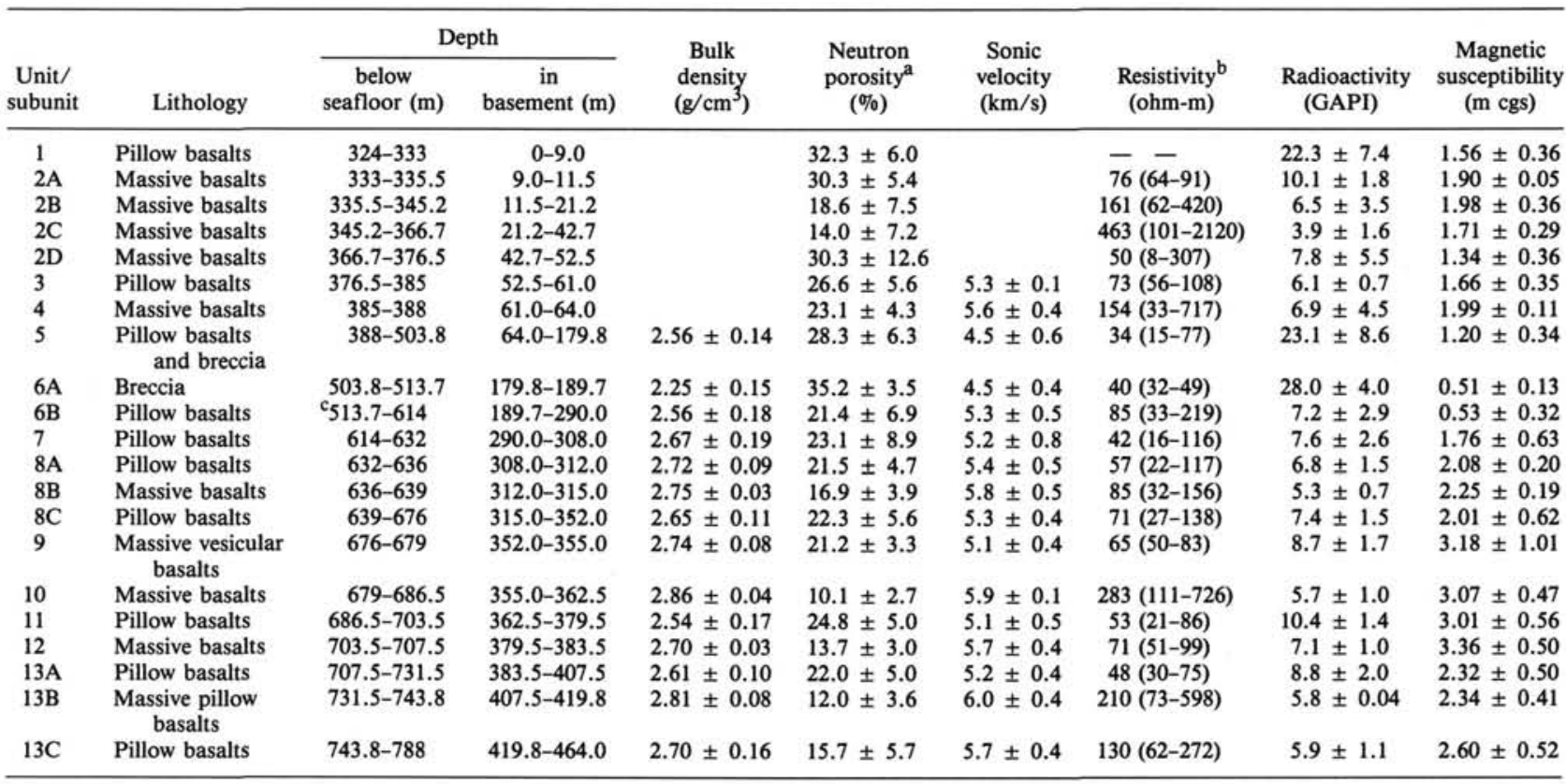

a Recorded through the pipe from 464 to 324 mbsf.

b Geometric mean from spherically focused log; geometric standard deviation limits in parentheses.

c Does not include data affected by bad hole conditions. 
Table 7. Average basement formation properties from logs in Hole 418A.

\begin{tabular}{|c|c|c|c|c|c|c|c|c|c|c|c|c|c|c|c|}
\hline $\begin{array}{l}\text { Logging } \\
\text { unit }\end{array}$ & $\begin{array}{c}\text { Lithologic } \\
\text { unit/subunit }\end{array}$ & $\begin{array}{c}\text { Depth in } \\
\text { basement (m) }\end{array}$ & $\begin{array}{c}\text { Total } \\
\text { porosity } \\
(\%)\end{array}$ & $\begin{array}{c}\text { Primary } \\
\text { porosity } \\
(\%)\end{array}$ & $\begin{array}{c}\text { Fracture } \\
\text { porosity } \\
(\%)\end{array}$ & $\begin{array}{c}\text { Bulk } \\
\text { density } \\
\left(\mathrm{g} / \mathrm{cm}^{3}\right)\end{array}$ & $\begin{array}{l}\text { Grain } \\
\text { density } \\
\left(\mathrm{g} / \mathrm{cm}^{3}\right)\end{array}$ & $\begin{array}{c}\mathrm{v}_{p} \\
(\mathrm{~km} / \mathrm{s})^{\mathrm{c}}\end{array}$ & $\begin{array}{c}\text { Matrix } \\
V_{p} \\
(\mathrm{~km} / \mathrm{s})\end{array}$ & $\begin{array}{l}\text { Radioactivity } \\
\text { (GAPI units) }\end{array}$ & $\begin{array}{l}\text { Alteration } \\
\text { (clay \%) }\end{array}$ & $\begin{array}{c}\text { Resistivity } \\
\text { (ohm-m) }\end{array}$ & $\begin{array}{c}\text { Clay bulk } \\
\text { density } \\
\left(\mathrm{g} / \mathrm{cm}^{3}\right)\end{array}$ & $\begin{array}{c}\text { Clay } \\
\mathrm{v}_{p} \\
(\mathrm{~km} / \mathrm{s})\end{array}$ & $\begin{array}{c}\text { Perme- } \\
\text { ability } \\
\text { ( } \mu \text { darcies) }\end{array}$ \\
\hline Hole 418A & $1-13 C$ & $0-464$ & 15.1 & 9.7 & 5.4 & $\mathrm{~d}_{2.58}$ & 2.95 & 5.07 & ${ }^{\circ} 6.22$ & 12.8 & 8.8 & - & - & - & - \\
\hline Unit 1 & $1-4$ & $0-64$ & 12.6 & 8.0 & 4.6 & - & - & 5.31 & - & 7.6 & 4.9 & - & - & - & - \\
\hline Unit 2 & $5-6 \mathrm{~A}$ & 64-189.7 & 19.7 & 13.5 & 6.2 & $d_{2.44}$ & - & 4.51 & - & 23.4 & 19.3 & - & - & - & - \\
\hline Unit 3 & $6 \mathrm{~B}-13 \mathrm{C}$ & $189.7-464$ & 13.1 & 7.7 & 5.4 & $d_{2.72}$ & - & 5.38 & - & 7.3 & 2.3 & - & - & - & - \\
\hline Core data & $1-16$ & $0-544$ & - & ${ }^{e_{5}}$ & - & $e_{2.83}$ & $\mathrm{f}_{2.95}$ & $e_{5.7}$ & ${ }^{\mathrm{e}} 6.4$ & - & - & $8_{120}$ & $\mathrm{~h}_{2.45}$ & $\mathrm{~h}_{4.01}$ & ${ }^{\mathrm{i}} 10^{-3}$ \\
\hline
\end{tabular}

${ }^{\text {a }}$ Broglia and Moos (this volume).

Shipboard Scientific Parties (1980b).

c Long-spaced sonic data.

${ }^{d}$ From $140 \mathrm{~m}$ within the basement.

e Average velocities for water-saturated samples at $0.1 \mathrm{kbar}$ differential confining pressure.

g Hamano (1980).

h Shipboard Scientific Parties (1980b)

i Johnson (1980). 

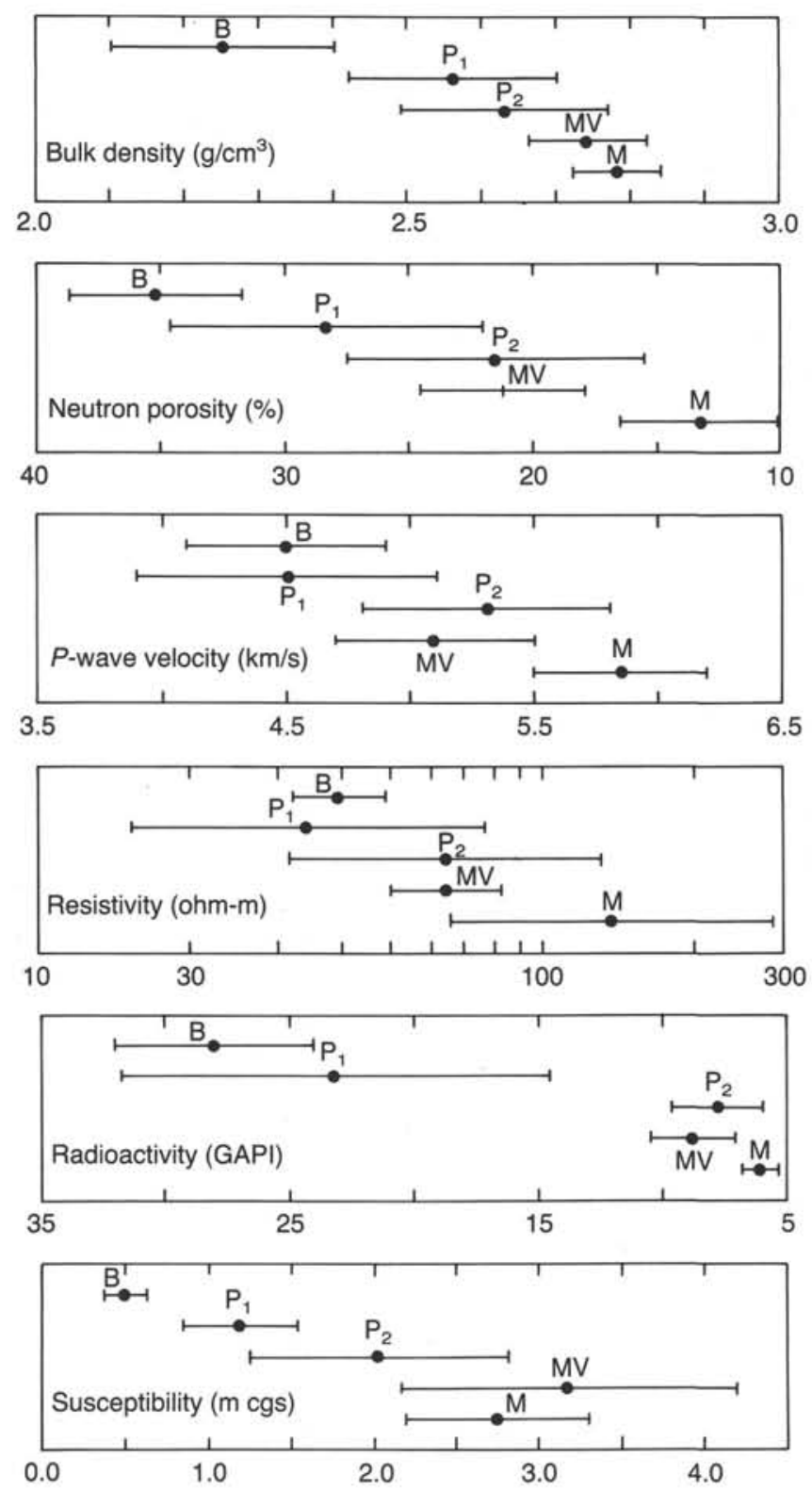

Figure 12. Average and statistical range ( \pm 1 s.d.) of uncorrected welllog values for breccia (B), altered pillow basalt $\left(\mathrm{P}_{1}\right)$, "fresh" pillow basalt $\left(\mathrm{P}_{2}\right)$, massive vesicular basalt $(\mathrm{MV})$, and massive basalt $(\mathrm{M})$ in Hole 418A. 


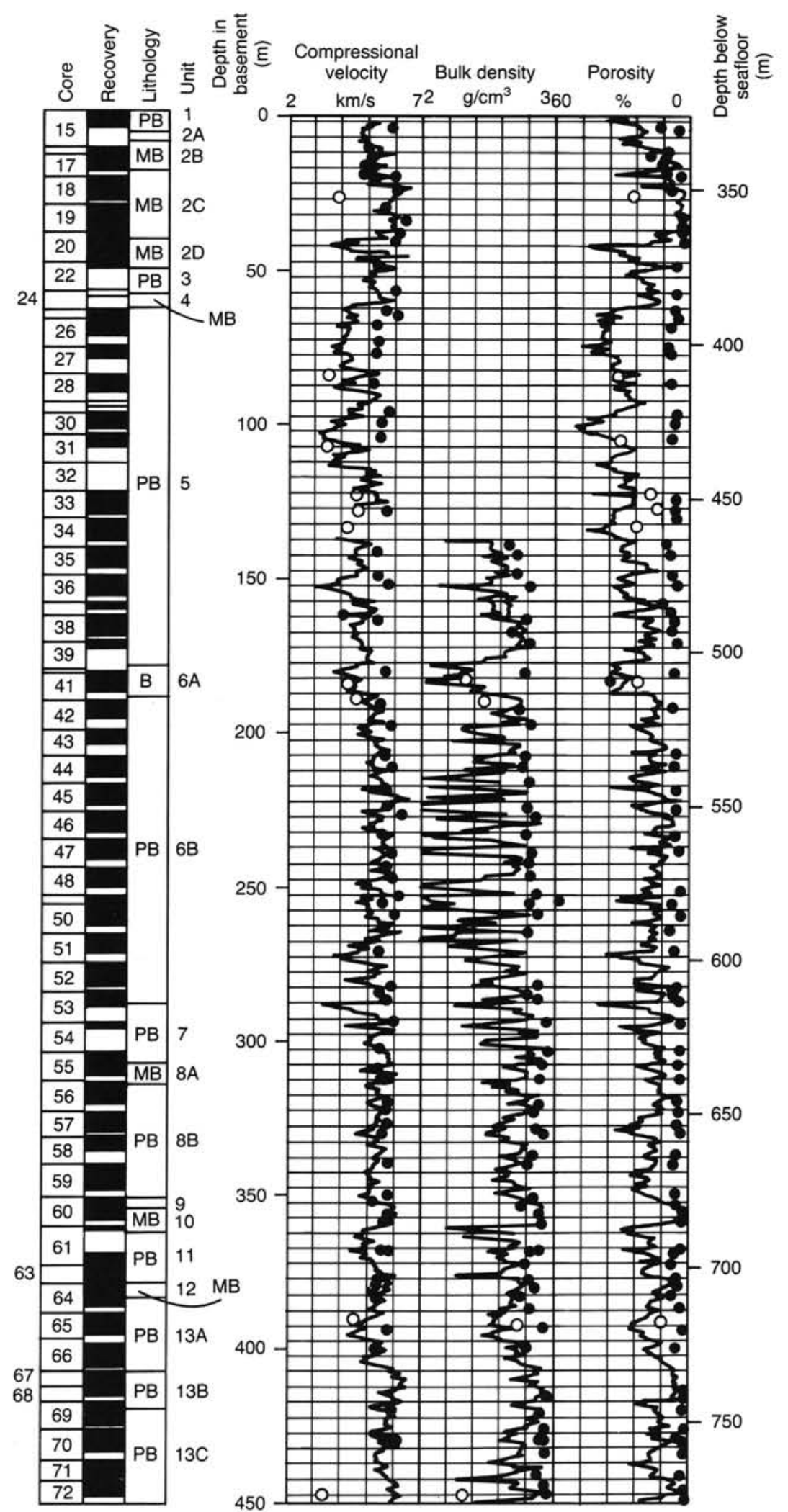

Figure 13. Comparison of compressional-wave velocity, density, and porosity data obtained from laboratory studies (Shipboard Scientific Parties, 1980b) and logging (Broglia and Moos, this volume) in Hole 418A. Laboratory velocities measured at atmospheric pressure; solid circles represent basalts, open circles clay fillings. $\mathrm{PB}=$ pillow basalt; $\mathrm{MB}=$ massive basalt; $\mathrm{B}=$ breccia . 
Table 8. Velocities, densities, and porosities of Hole 418A basalts.

\begin{tabular}{|c|c|c|c|c|c|c|c|c|c|c|c|}
\hline \multirow[b]{2}{*}{ Sample } & \multirow[b]{2}{*}{ Rock type } & \multirow{2}{*}{$\begin{array}{c}\text { Bulk } \\
\text { density } \\
\left(\mathrm{g} / \mathrm{cm}^{3}\right)\end{array}$} & \multirow{2}{*}{$\begin{array}{l}\text { Porosity } \\
(\%)\end{array}$} & \multicolumn{8}{|c|}{$\begin{array}{l}\text { Velocity }(\mathrm{km} / \mathrm{s}) \\
\text { at varying pressures (kbar) }\end{array}$} \\
\hline & & & & & $0.1^{\mathrm{a}}$ & 0.2 & 0.4 & 0.6 & 0.8 & 1.0 & 2.0 \\
\hline $418 \mathrm{~A}-15-1,28-30$ & Pillow basalt & 2.728 & 1.6 & $\mathrm{~V}_{p}:$ & 5.36 & 5.38 & 5.41 & 5.44 & 5.46 & 5.48 & 5.58 \\
\hline $418 \mathrm{~A}-16-3,44-47$ & Altered massive & 2.613 & 5.6 & & 4.70 & 4.73 & 4.79 & 4.83 & 4.87 & 4.90 & 5.01 \\
\hline $418 \mathrm{~A}-18-1,47-50$ & $\begin{array}{l}\text { basalt } \\
\text { Massive basalt }\end{array}$ & 2.864 & 1.2 & & 2.51 & 2.56 & 2.60 & 2.63 & 2.65 & 2.6 & $\begin{array}{l}2.70 \\
6.30\end{array}$ \\
\hline $418 \mathrm{~A}-20-2,94-96$ & Massive basalt & 2.903 & 0.5 & $\begin{array}{l}v_{p}: \\
v_{p}:\end{array}$ & $\begin{array}{l}6.03 \\
6.24\end{array}$ & $\begin{array}{l}6.06 \\
6.27\end{array}$ & $\begin{array}{l}6.11 \\
6.32\end{array}$ & $\begin{array}{l}6.14 \\
6.36\end{array}$ & $\begin{array}{l}6.17 \\
6.39\end{array}$ & $\begin{array}{l}6.20 \\
6.41\end{array}$ & $\begin{array}{l}0.30 \\
6.49\end{array}$ \\
\hline $418 \mathrm{~A}-25-1,145-147$ & Pillow basalt & 2.802 & 2.2 & $v_{p}:$ & 5.54 & 5.57 & 5.62 & 5.66 & 5.69 & 5.72 & 5.82 \\
\hline \multirow[t]{2}{*}{$418 \mathrm{~A}-26-3,21-24$} & Pillow basalt & 2.716 & 2.8 & $v_{p}$ : & 5.18 & 5.21 & 5.25 & 5.28 & 5.31 & 5.33 & 5.42 \\
\hline & & & & $\mathrm{v}_{s}:$ & 2.87 & 2.89 & 2.91 & 2.92 & 2.93 & 2.93 & 2.95 \\
\hline $418 \mathrm{~A}-28-1,130-132$ & Pillow basalt & 2.714 & 1.4 & $\mathrm{v}_{p}:$ & 5.34 & 5.38 & 5.45 & 5.50 & 5.53 & 5.56 & 5.66 \\
\hline $418 \mathrm{~A}-30-4,23-26$ & Pillow basalt & 2.696 & 1.9 & $\mathrm{v}_{p}$ & 5.44 & 5.47 & 5.53 & 5.56 & 5.59 & 5.61 & 5.69 \\
\hline $418 \mathrm{~A}-33-1,79-81$ & Pillow basalt & 2.829 & 0.7 & $\mathrm{v}_{p}:$ & 5.89 & 5.91 & 5.95 & 5.98 & 6.01 & 6.03 & 6.10 \\
\hline \multirow[t]{2}{*}{$418 \mathrm{~A}-35-1,28-30$} & Pillow basalt & 2.663 & 3.5 & $v_{p}:$ & 5.08 & 5.09 & 5.11 & 5.13 & 5.16 & 5.17 & 5.27 \\
\hline & & & & $v_{s}:$ & 2.73 & 2.76 & 2.79 & 2.80 & 2.82 & 2.83 & 2.86 \\
\hline \multirow[t]{2}{*}{$418 A-35-5,22-24$} & Altered pillow & 2.532 & 5.0 & $\mathrm{~V}_{p}:$ & 4.60 & 4.62 & 4.65 & 4.68 & 4.70 & 4.72 & 4.82 \\
\hline & basalt & & & & 2.46 & 2.49 & 2.51 & 2.53 & 2.54 & 2.55 & 2.59 \\
\hline $418 \mathrm{~A}-39-2,40-42$ & Pillow basalt & 2.802 & 0.8 & $\mathrm{v}_{p}:$ & 5.79 & 5.81 & 5.84 & 5.87 & 5.89 & 5.91 & 5.98 \\
\hline $418 A-41-1,94-96$ & Breccia & 2.800 & 3.8 & $v_{p}$ & 5.5 & 5.60 & 5.64 & 5.66 & 5.68 & 5.70 & 5.78 \\
\hline $418 A-41-3,62-65$ & Breccia & 2.359 & 9.7 & $V_{p}:$ & 3.91 & 3.98 & 4.12 & 4.24 & 4.35 & 4.44 & 4.65 \\
\hline $418 A-42-4,63-65$ & Pillow basalt & 2.787 & 0.6 & & 5.58 & 5.60 & 5.64 & 5.67 & 5.69 & 5.71 & 5.78 \\
\hline \multirow[t]{2}{*}{$418 A-44-1,43-46$} & Pillow basalt & 2.792 & 0.9 & $v_{p}$ & 5.81 & 5.83 & 5.87 & 5.90 & 5.93 & 5.96 & 6.03 \\
\hline & & & & $\mathbf{v}_{s}$ & 3.19 & 3.20 & 3.23 & 3.24 & 3.25 & 3.26 & 3.29 \\
\hline $418 \mathrm{~A}-46-1,10-12$ & Pillow basalt & 2.800 & 1.0 & $\mathrm{v}_{p}:$ & 5.81 & 5.83 & 5.86 & 5.89 & 5.91 & 5.93 & 6.02 \\
\hline $418 \mathrm{~A}-48-1,26-28$ & Pillow basalt & 2.794 & 0.7 & $v_{p}:$ & 5.87 & 5.90 & 5.95 & 5.98 & 6.01 & 6.03 & 6.10 \\
\hline $418 \mathrm{~A}-49-2,102-104$ & Pillow basalt & 2.811 & 1.0 & $v_{p}:$ & 5.94 & 5.95 & 5.96 & 5.98 & 5.99 & 6.00 & 6.06 \\
\hline $418 \mathrm{~A}-51-2,100-102$ & Pillow basalt & 2.813 & 1.2 & $v_{p}:$ & 5.70 & 5.73 & 5.78 & 5.83 & 5.86 & 5.90 & 6.01 \\
\hline \multirow[t]{2}{*}{$418 \mathrm{~A}-52-3,132-134$} & Pillow basalt & 2.844 & 2.2 & $v_{p}:$ & 5.78 & 5.81 & 5.86 & 5.90 & 5.93 & 5.96 & 6.07 \\
\hline & & & & $v_{s}:$ & 3.30 & 3.32 & 3.34 & 3.36 & 3.37 & 3.38 & 3.41 \\
\hline $418 A-54-2,7-9$ & Pillow basalt & 2.919 & 0.9 & $V_{p}$ & 6.05 & 6.08 & 6.14 & 6.18 & 6.21 & 6.24 & 6.32 \\
\hline $418 A-55-2,2-4$ & Pillow basalt & 2.908 & 2.3 & & 5.92 & 5.94 & 5.98 & 6.02 & 6.05 & 6.07 & 6.16 \\
\hline $418 \mathrm{~A}-56-1,110-112$ & Pillow basalt & 2.861 & 1.2 & & 5.97 & 5.99 & 6.02 & 6.05 & 6.07 & 6.09 & 6.19 \\
\hline $418 \mathrm{~A}-57-2,122-124$ & Pillow basalt & 2.854 & 0.9 & & 5.86 & 5.87 & 5.89 & 5.90 & 5.92 & 5.93 & 6.00 \\
\hline \multirow[t]{2}{*}{$418 \mathrm{~A}-60-6,21-23$} & Massive basalt & 2.870 & 0.7 & & 6.11 & 6.12 & 6.13 & 6.15 & 6.16 & 6.18 & 6.24 \\
\hline & & & & & 3.29 & 3.31 & 3.35 & 3.37 & 3.39 & 3.41 & 3.46 \\
\hline $418 \mathrm{~A}-61-1,5-7$ & Massive basalt & 2.903 & 0.6 & $\mathrm{v}_{p}:$ & 5.94 & 5.97 & 6.02 & 6.06 & 6.09 & 6.12 & 6.22 \\
\hline $418 A-63-5,44-46$ & Pillow basalt & 2.833 & 3.3 & $\mathrm{v}_{p}^{p}$ & 5.69 & 5.71 & 5.75 & 5.79 & 5.83 & 5.89 & 5.97 \\
\hline $418 \mathrm{~A}-64-1,89-91$ & Massive basalt & 2.810 & 3.0 & $\mathrm{v}_{p}$ : & 5.72 & 5.75 & 5.80 & 5.84 & 5.87 & 5.90 & 6.03 \\
\hline $418 \mathrm{~A}-65-1,63-65$ & Pillow basalt & 2.812 & 3.0 & $V_{p}:$ & 5.49 & 5.52 & 5.57 & 5.59 & 5.62 & 5.65 & 5.74 \\
\hline \multirow[t]{2}{*}{$418 \mathrm{~A}-67-1,40-42$} & Pillow basalt & 2.929 & 1.2 & $\mathrm{v}_{p}:$ & 6.05 & 6.07 & 6.13 & 6.17 & 6.21 & 6.24 & 6.36 \\
\hline & & & & $\mathrm{v}_{s}$ & 3.36 & 3.38 & 3.40 & 3.42 & 3.44 & 3.45 & 3.50 \\
\hline $418 \mathrm{~A}-69-1,95-97$ & Pillow basalt & 2.912 & 0.9 & $v_{p}:$ & 6.14 & 6.17 & 6.22 & 6.26 & 6.28 & 6.31 & 6.40 \\
\hline $418 \mathrm{~A}-71-1,18-20$ & Pillow basalt & 2.917 & 1.2 & & 6.15 & 6.17 & 6.20 & 6.23 & 6.26 & 6.28 & 6.35 \\
\hline $418 \mathrm{~A}-73-1,106-108$ & Pillow basalt & 2.935 & 0.4 & & 6.28 & 6.31 & 6.36 & 6.39 & 6.42 & 6.44 & 6.53 \\
\hline \multirow[t]{2}{*}{$418 \mathrm{~A}-74-1,98-100$} & Pillow basalt & 2.940 & 0.5 & $\mathrm{~V}_{p}:$ & 6.38 & 6.39 & 6.40 & 6.42 & 6.43 & 6.45 & 6.50 \\
\hline & & & & $s^{*}$ & 3.52 & 3.54 & 3.56 & 3.57 & 3.58 & 3.58 & 3.60 \\
\hline $418 \mathrm{~A}-77-5,26-28$ & Massive basalt & 2.869 & 1.1 & $\mathrm{v}_{p}:$ & 6.06 & 6.08 & 6.11 & 6.14 & 6.17 & 6.19 & 6.27 \\
\hline $418 A-78-6,65-67$ & Massive basalt & 2.904 & 0.6 & $v_{p}:$ & 6.24 & 6.26 & 6.30 & 6.33 & 6.36 & 6.38 & 6.45 \\
\hline $418 A-79-3,67-69$ & Massive basalt & 2.920 & 0.8 & $p^{*}$ & 6.37 & 6.39 & 6.42 & 6.45 & 6.48 & 6.49 & 6.56 \\
\hline $418 \mathrm{~A}-80-2,68-70$ & Massive basalt & 2.921 & 0.5 & $\mathrm{~V}_{p}$ & 6.26 & 6.28 & 6.31 & 6.34 & 6.36 & 6.38 & 6.46 \\
\hline \multirow[t]{2}{*}{$418 \mathrm{~A}-81-5,110-112$} & Massive basalt & 2.935 & 0.4 & $v_{p}:$ & 6.37 & 6.40 & 6.45 & 6.48 & 6.50 & 6.53 & 6.60 \\
\hline & & & & & 3.55 & 3.58 & 3.61 & 3.62 & 3.63 & 3.64 & 3.65 \\
\hline $418 \mathrm{~A}-82-1,125-127$ & Massive basalt & 2.929 & 0.0 & $\mathrm{v}_{p}$ & 6.25 & 6.28 & 6.33 & 6.37 & 6.40 & 6.43 & 6.55 \\
\hline $418 \mathrm{~A}-83-2,56-58$ & Massive basalt & 2.916 & 0.2 & $v_{p}:$ & 6.33 & 6.39 & 6.50 & 6.56 & 6.61 & 6.64 & 6.76 \\
\hline $418 \mathrm{~A}-84-2,22-24$ & Massive basalt & 2.907 & 1.0 & $v_{p}:$ & 6.22 & 6.25 & 6.30 & 6.33 & 6.36 & 6.38 & 6.48 \\
\hline $418 A-85-2,7-9$ & Massive basalt & 2.955 & 0.1 & $v_{p}$ & 6.43 & 6.47 & 6.56 & 6.61 & 6.65 & 6.68 & 6.80 \\
\hline & & & & $\mathrm{v}_{s}$ & 3.51 & 3.55 & 3.59 & 3.61 & 3.63 & 3.64 & 3.68 \\
\hline $418 \mathrm{~A}-86-2,71-73$ & Pillow basalt & 2.876 & 1.7 & $v_{p}:$ & 5.97 & 5.99 & 6.03 & 6.06 & 6.08 & 6.10 & 6.18 \\
\hline
\end{tabular}

Note: Compressional wave velocities, densities, and porosities from Christensen et al., 1980; shear wave velocities, this study.

a Compressional wave velocity data at 0.1 kbar extrapolated from slope and velocity at $0.2 \mathrm{kbar}$. 


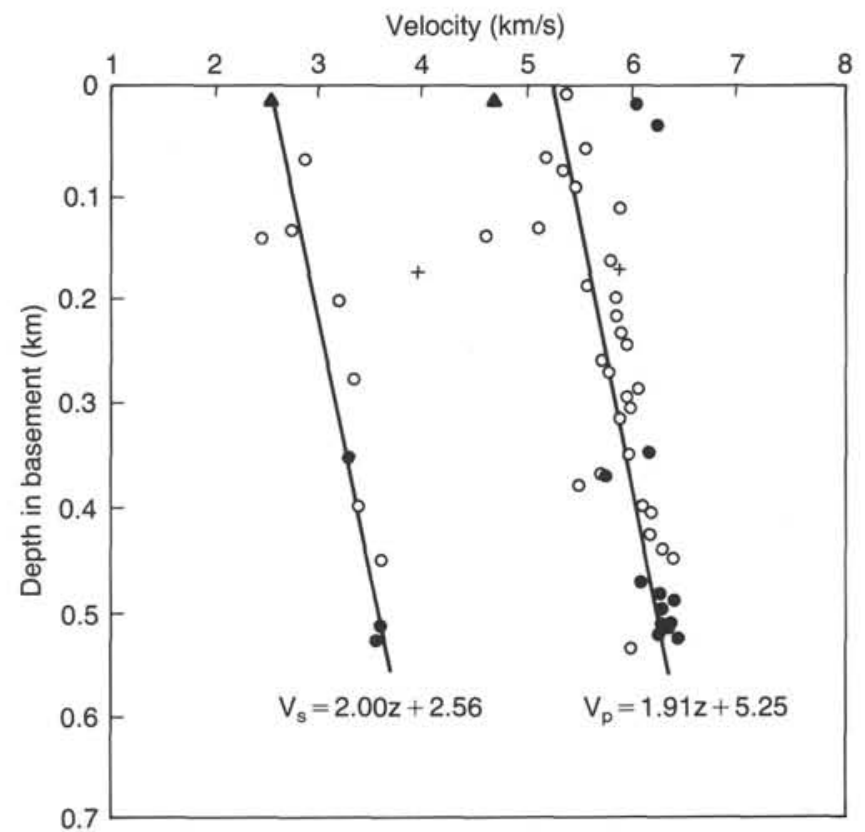

Figure 14. Laboratory values of compressional- $\left(\mathrm{V}_{p}\right)$ and shear- $\left(\mathrm{V}_{s}\right)$ wave velocities for massive basalt (solid circles), altered massive basalt (triangles), pillow basalt (open circles), and breccia (crosses) samples from Hole $418 \mathrm{~A}$ at $0.1-\mathrm{kbar}$ confining pressure (Table 8). Solid lines represent least-squares fits to data.

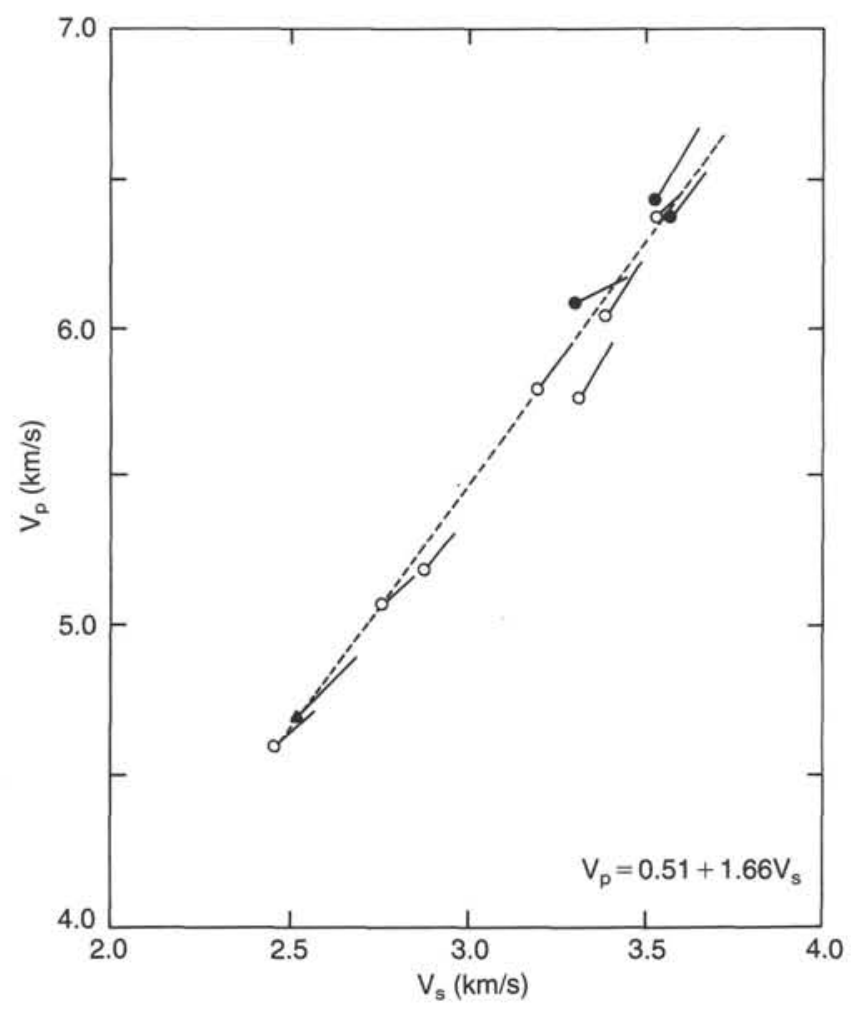

Figure 15. Crossplot of compressional- $\left(\mathrm{V}_{p}\right)$ and shear- $\left(\mathrm{V}_{s}\right)$ wave velocities obtained from laboratory studies of samples from Hole $418 \mathrm{~A}$ at confining pressure of 0.1 (symbols as in Fig. 14) to $1.0 \mathrm{kbar}$ (ends of tails). Dotted line and equation represent least-squares fit to data. 


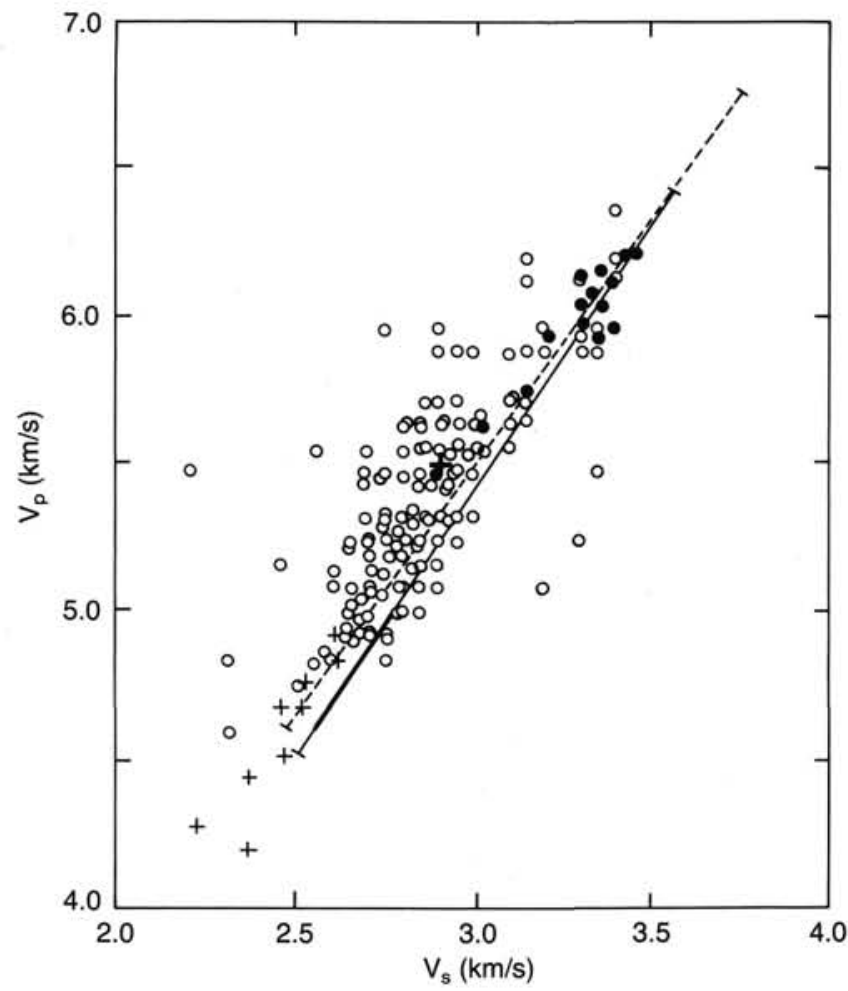

Figure 16. Crossplot of compressional- $\left(\mathrm{V}_{p}\right)$ and shear- $\left(\mathrm{V}_{s}\right)$ wave velocities obtained in Hole 418A from multichannel sonic (MCS) logging. Symbols as in Figure 14; dark cross represents average of $\mathrm{V}_{p}$ and $\mathrm{V}_{s}$ data. Also shown for comparison are least-squares fit to laboratory data from Figure 15 (dotted line) and ranges of data obtained by $\tau-\zeta$ inversion (solid line) and inflection point analysis (solid bar) of OSE data.

Table 9. Comparison of average velocities determined in the upper 0.5 km of the crust at Site 418 by laboratory, logging, and seismic techniques.

\begin{tabular}{lcccc}
\hline \multicolumn{1}{c}{ Method } & $\begin{array}{c}\text { Depth interval } \\
(\mathrm{m} \text { in basement) }\end{array}$ & $\begin{array}{c}\mathrm{V}_{p} \\
(\mathrm{~km} / \mathrm{s})\end{array}$ & $\begin{array}{c}\mathrm{V}_{s} \\
(\mathrm{~km} / \mathrm{s})\end{array}$ & $\begin{array}{c}\text { Propagation } \\
\text { direction }^{\mathrm{a}}\end{array}$ \\
\hline Laboratory (0.1 kbar) & $0-538$ & 5.7 & 3.1 & $\mathrm{H} / \mathrm{V}$ \\
$\begin{array}{l}\text { Logging } \\
\text { Multichannel sonic }\end{array}$ & $145-464$ & 5.5 & 2.9 & $\mathrm{~V}$ \\
$\quad \begin{array}{l}\text { Long-spaced sonic } \\
\text { OSE }\end{array}$ & $0-464$ & 5.1 & - & $\mathrm{V}$ \\
$\quad$ Inflection & $41-430$ & $\mathrm{~b}_{4.8} \pm 0.2$ & 2.7 & $\mathrm{H}$ \\
$\quad$ VSP & $81-430$ & 4.6 & - & $\mathrm{V}$ \\
\hline
\end{tabular}

${ }^{\mathrm{a}} \mathrm{H}=$ horizontal; $\mathrm{V}=$ vertical.

bange due to azimuthal anisotropy. 


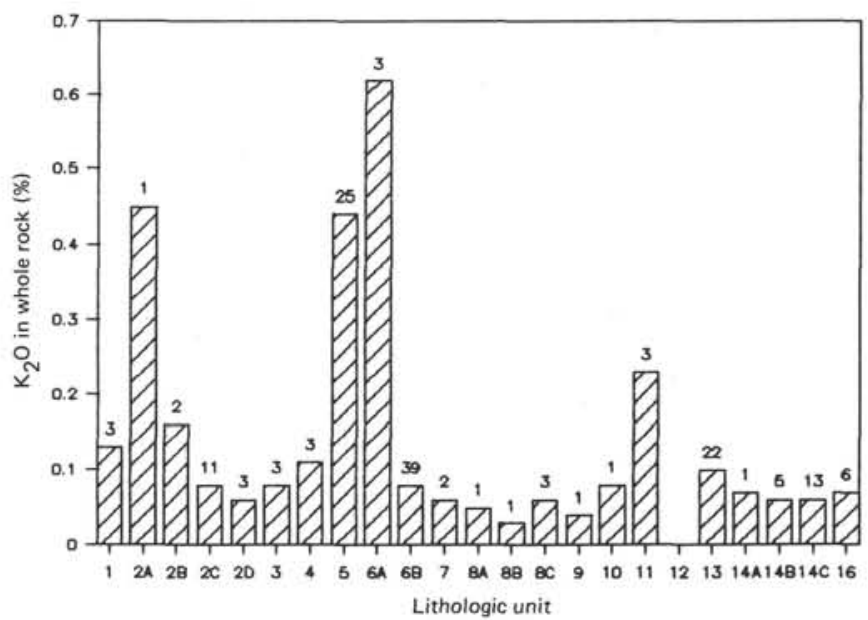

Figure 17. Average $\mathrm{K}_{2} \mathrm{O}$ content of Units 1-16 in Hole 418A from whole-rock X-ray fluorescence analyses (after Flower et al., 1980). Numbers above bars indicate number of samples analyzed for each unit. 


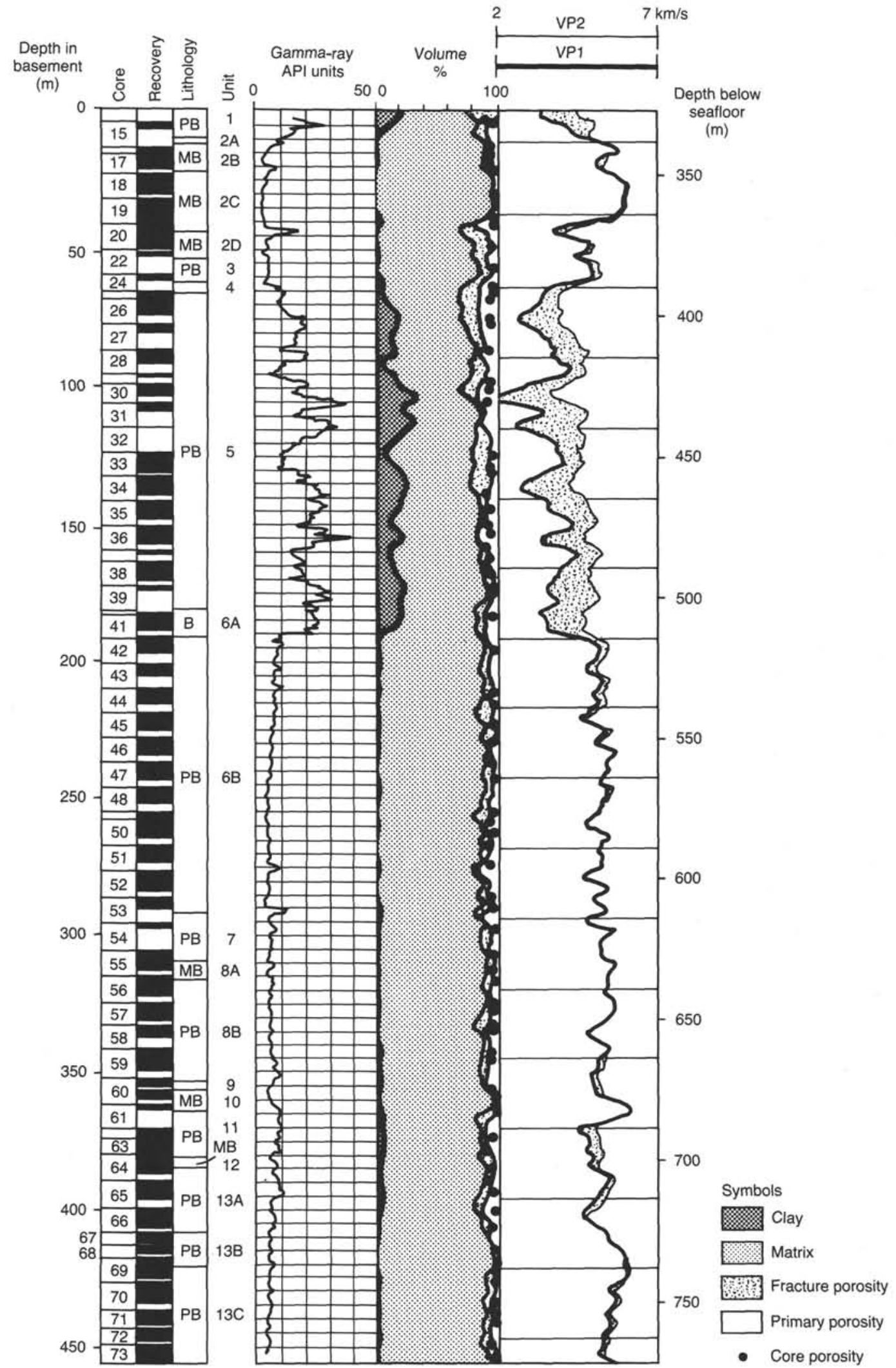

Figure 18. Comparison of natural gamma-ray log, clay content (computed from natural gamma-ray log), total porosity (from corrected neutron $\mathrm{log}$ ), primary porosity (from sonic log), sample porosities (solid circles), and original velocity vs. depth, assuming partial $\left(\mathrm{V}_{p 2}\right)$ to complete $\left(\mathrm{V}_{p 1}\right)$ substitution of water for clay (after Broglia and Moos, this volume). $\mathrm{PB}=$ pillow basalt; $\mathrm{MB}=$ massive basalt; $\mathrm{B}=$ breccia. 


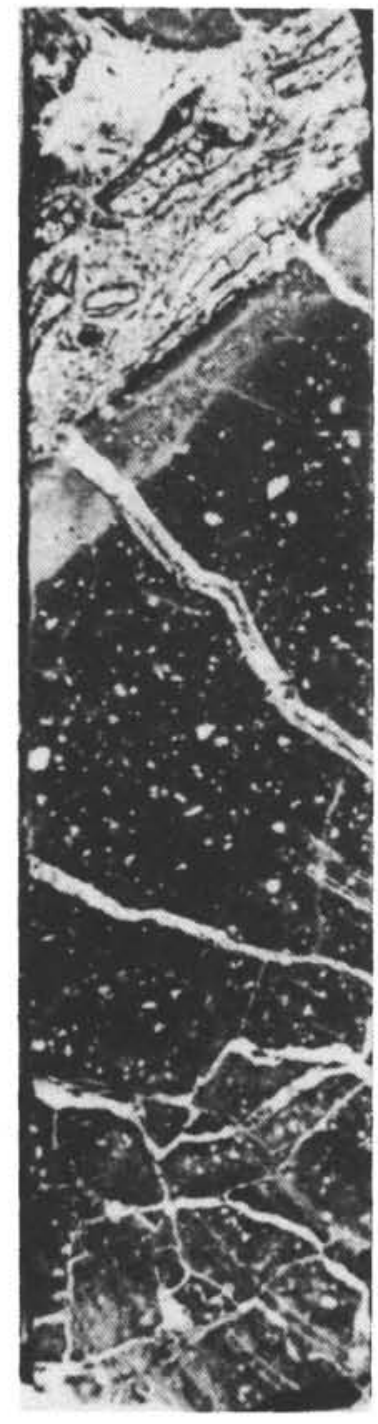

1

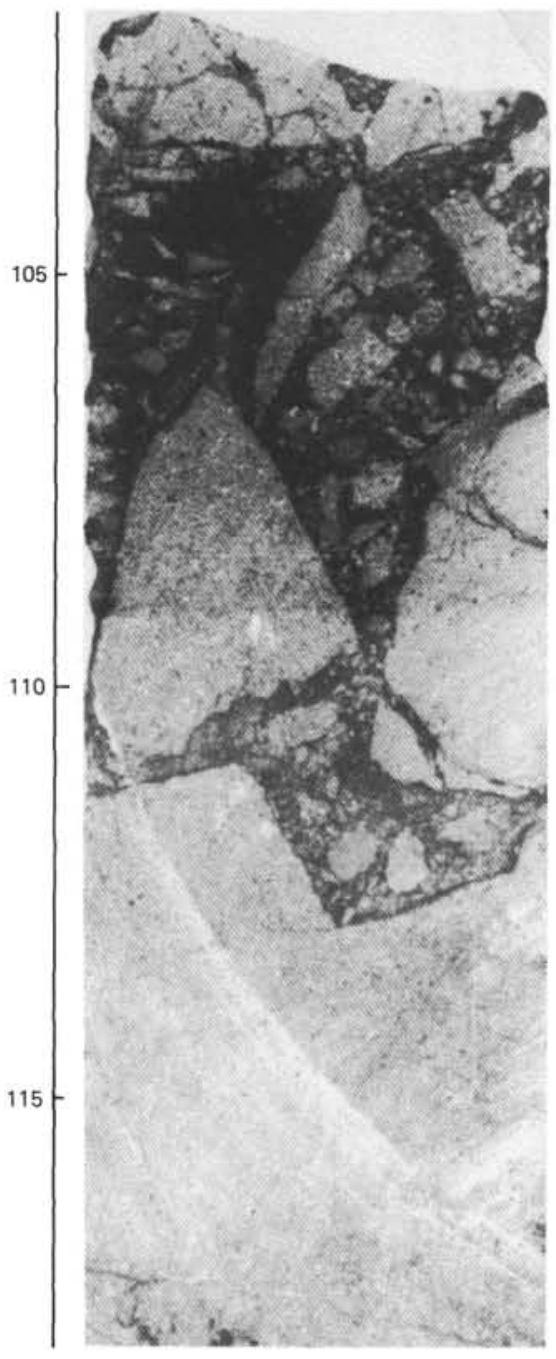

2

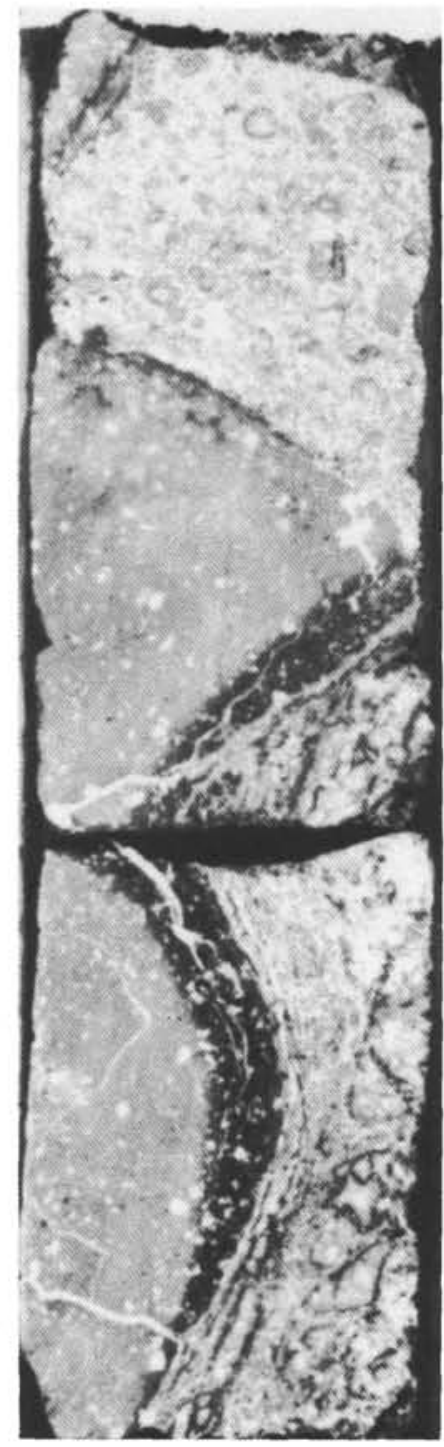

3

Plate 1. Macroscopic features of basalts from Holes 417A and 417D. 1. Sample 417A-24-2, 100-125 cm. Core width, $6 \mathrm{~cm}$. Pillow margin with a 2-cm-thick yellowish groundmass (pale gray) and a 2-mm-thick dark brown outer rim cut by radial calcite, hematite, and chlorite-filled veins. Pillow matrix consists of elongate, green palagonite shards in a fine-grained self-matrix cemented by calcite (Juteau et al., 1980). 2. Sample 417D-59-1, $102-118 \mathrm{~cm}$. Core width, $6 \mathrm{~cm}$. Broken pillow breccia in a matrix of glass debris altered to smectite (Robinson et al., 1980). 3. Sample 417A-24-2, $59-80 \mathrm{~cm}$. Core width, $6 \mathrm{~cm}$. Basalt pillow fragments in a matrix of hyaloclastic breccia. Note exfoliation of marginal glassy spalls and alteration and swelling accompanying hydration (Shipboard Scientific Parties, 1980a). 